\title{
Metal(loid) speciation and transformation by aerobic methanotrophs
}

\author{
Obulisamy Parthiba Karthikeyan 1,2,3* ${ }^{\text {, Thomas J. Smith }}{ }^{4^{*}}$, Shamsudeen Umar Dandare ${ }^{1}$, Kamaludeen Sara Parwin ${ }^{5}$, \\ Heetasmin Singh ${ }^{6}$, Hui Xin Loh', Mark R Cunningham', Paul Nicholas Williams', Tim Nichol', \\ Avudainayagam Subramanian ${ }^{5}$, Kumarasamy Ramasamy ${ }^{7}$ and Deepak Kumaresan ${ }^{{ }^{*}}$ (D)
}

\begin{abstract}
Manufacturing and resource industries are the key drivers for economic growth with a huge environmental cost (e.g. discharge of industrial effluents and post-mining substrates). Pollutants from waste streams, either organic or inorganic (e.g. heavy metals), are prone to interact with their physical environment that not only affects the ecosystem health but also the livelihood of local communities. Unlike organic pollutants, heavy metals or trace metals (e.g. chromium, mercury) are non-biodegradable, bioaccumulate through food-web interactions and are likely to have a long-term impact on ecosystem health. Microorganisms provide varied ecosystem services including climate regulation, purification of groundwater, rehabilitation of contaminated sites by detoxifying pollutants. Recent studies have highlighted the potential of methanotrophs, a group of bacteria that can use methane as a sole carbon and energy source, to transform toxic metal (loids) such as chromium, mercury and selenium. In this review, we synthesise recent advances in the role of essential metals (e.g. copper) for methanotroph activity, uptake mechanisms alongside their potential to transform toxic heavy metal (loids). Case studies are presented on chromium, selenium and mercury pollution from the tanneries, coal burning and artisanal gold mining, respectively, which are particular problems in the developing economy that we propose may be suitable for remediation by methanotrophs.
\end{abstract}

Keywords: Methanotrophs, Metalloenzymes, Methanobactin, Metal transformation and speciation, Bioremediation

\section{Introduction}

The world's population is predicted to reach 9.7 billion by 2050. Increasing demand for food and energy contributes to over-exploitation of natural resources and environmental degradation. Particularly, release of pollutants into the environment from manufacturing and resource industries is a major concern for ecosystem health. Pollutants, either organic (e.g. polycyclic aromatic hydrocarbons) or inorganic (e.g. heavy metals), when they interact with their physical environment, not only affect the quality of the

\footnotetext{
*Correspondence: pobulisa@umich.edu; T.J.Smith@shu.ac.uk; d.kumaresan@qub.ac.uk

'School of Biological Sciences \& Institute for Global Food Security, Queen's University Belfast, 19 Chlorine Gardens, Belfast, UK

${ }^{4}$ Biomolecular Sciences Research Centre, Sheffield Hallam University, Sheffield, UK

Full list of author information is available at the end of the article
}

environment but also have cascading effects on the health and wellbeing of organisms across all domains of life [1,2]. Unlike organic pollutants, heavy metal(loid)s or trace metals (e.g. chromium-Cr, mercury-Hg, selenium-Se) are non-biodegradable, persist longer in the environment and bioaccumulate through the food web. Even at low concentrations, they are likely to have a long-term impact on ecosystem health $[3,4]$. Naturally occurring metals are integral to the evolution of living organisms and are critical for metabolic activities e.g. co-factors for enzymes [5]. Despite their biological importance, large amounts of these metals can result in cellular and tissue damage, i.e. cytotoxicity in animals and growth inhibition in microbes; poor growth, low yields and nutrient inbalances in plants and metabolic interferences and mutangenesis in all types of organisms $[6,7]$. Detailed reviews on the occurrence of heavy metals 
in the environment, industrial production and usage, potential for human exposure, and their molecular mechanisms of toxicity can be found in [8-11]. In this review, we also highlight the impact of tannery industries (i.e. Cr pollution - Table 1), selenium-polluting industries including mining (Table 2), and artisinal gold mining (i.e. $\mathrm{Hg}$ pollution - Table 3 ) as case studies.

Current remediation strategies of contaminated sites include chemical extraction (with acids or chelating agents), immobilisation, encapsulation and electrolysis. Although these strategies have been useful, they come with several limitations including significant alterations of the physicochemical properties, low efficiency and high cost of operation [38]. Phyto/bioremediation has been suggested as an alternative eco-friendly approach to detoxify metals from contaminated sites [39]. This approach leverages intrinsic biological mechanisms of plants and microorganisms to transform and/or

Table 1 Chromium pollution from tannery industries-a case study

Tannery industries contribute significiantly to the developing economies such as India and Bangladesh ( 3.5 and 5 billion USD per annum,

respectively). Leather production utilises a large amount of water. It has been estimated that about $25-40 \mathrm{~m}^{3}$ of fresh/ground water resources is used and subsequently discharged into the environment as effluent during the processing of one tonne of hides. Tannery effluents generally contain high levels of organics (measured as biological/chemical oxygen demand), nitrogen, sulphate and heavy metals such as $\mathrm{Cr}, \mathrm{Ni}$, As and $\mathrm{Co}$. Tanneries have been the subject of wide public debate, particularly the downstream pollution by carcinogenic and teratogenic $\mathrm{Cr}(\mathrm{VI})$ that leaches into water bodies and soil and its subsequent impact on ecosystem health. For example, the Vellore district in South India is a well-known tannery hub that is famous for its export of leather [12]. Extensive surveys on tannery-associated groundwater contamination have revealed that toxic $\mathrm{Cr}(\mathrm{VI})$ can be detected (even at a depth of $10 \mathrm{~m}$ ) at a high concentration up to $38 \mathrm{mg} \mathrm{L}^{-1}$ (critical limit $0.05 \mathrm{mg} \mathrm{L}^{-1}$ [13];) in the Ranipet, Walajapet and Vaniambadi areas of the Vellore district. This is extremely high compared to levels reported in other parts of India (4$\left.7 \mathrm{mg} \mathrm{L}^{-1}\right)$ [14].

Chromium pollution from tanneries extends to soil e.g. about 50,000 ha of agricultural land has been affected due to salts and chromium from the tannery waste streams. Concentrations of exchangeable $\mathrm{Cr}$ fractions have been reported up to $128 \mathrm{\mu g} \mathrm{kg}^{-1}$. Research in sites dumped with tannery wastes over the past 20 years in Vellore and surrounding regions has indicated that soil alkalinity facilitates the presence of the more toxic and mobile $\mathrm{Cr}(\mathrm{VI})$ that subsequently leaches into the groundwater. Alarming levels of $\mathrm{Cr}$ were also found in borewell waters in Palar river basin (>500 $\left.\mu \mathrm{g} \mathrm{Cr} \mathrm{L}^{-1}\right), 90 \%$ of which was Cr(VI) [15]. In highly contaminated zones, the total $\mathrm{Cr}$ was reported to be as high as $102 \mathrm{~g} \mathrm{Cr} \mathrm{kg}^{-1}$ soil and has been found even at soil depth of $30 \mathrm{~cm}(1.1$ $\mathrm{mg} \mathrm{Cr}(\mathrm{VI}) \mathrm{kg}^{-1}[16,17]$. While tanneries use $\mathrm{Cr}(\mathrm{III})$ salts for leather processing, the presence of $\mathrm{Cr}(\mathrm{VI})$ in the contaminated sites is still an intriguing question. Contrary to the general acceptance that the presence of organic matter and other species contributing to electron transfer reactions in soil would rapidly convert $\mathrm{Cr}(\mathrm{VI})$ to $\mathrm{Cr}(\mathrm{III})$, these soils showed higher levels of $\mathrm{Cr}(\mathrm{VI})$ despite high-soil organic content (15\%) [16]. It has also been reported that high concentrations of sodium and phosphates in soil solution can also trigger $\mathrm{Cr}(\mathrm{VI})$ mobility in soils with alkaline $\mathrm{pH}$ [18]. In addition manganese oxides are reported to reoxidise $\mathrm{Cr}(\mathrm{III})$ to $\mathrm{Cr}(\mathrm{VI})$ [19]. While tanners are replacing tannins instead of chromium, remediation of $\mathrm{Cr}(\mathrm{VI})$ in long-term contaminated soils have not been successful owing to reoxidation of $\mathrm{Cr}(\mathrm{III})$ to $\mathrm{Cr}(\mathrm{VI})$ [20] and continue to be an major issue.
Table 2 Selenium an essential element with toxicity problems in the mining industry and beyond

The Recommended Daily Intake of selenium in the human diet is $55 \mathrm{mg}$ $\mathrm{d}^{-1}$ (dietary reference intakes, 2000; Dietary Reference Intakes (2000) National Research Council. Washington: National Academic Press). The World Health Organization (WHO) has indicated that Se intake in the human diet in excess of $400 \mathrm{mg} \mathrm{d}^{-1}$ may be harmful to health, with signs of Se overexposure being evident at 750-858 $\mathrm{mg} \mathrm{d}^{-1}$ [21]. Potentially, toxic levels of selenium in the environment may occur naturally due to the presence of seleniferous rocks and also due to human activities, particularly mining. Selenium concentrations in agricultural drainage water in the range $0.14-1.4 \mathrm{mg} \mathrm{L}^{-1}$ were reported to cause death and deformity in aquatic birds [22]. The WHO has set the maximum permitted Se concentration for drinking water at $40 \mathrm{mg} \mathrm{L}^{-1}$, although specific jurisdictions have set limits as low as $10 \mathrm{mg} \mathrm{L}^{-1}$. Water quality guidelines for freshwater and water used for agricultural irrigation water range from 1 to $150 \mathrm{mg} \mathrm{L}^{-1}$ [23]. Selenium is strongly enriched in coal compared to other rocks and so coal and the ash from coal combustion are major sources of toxic amounts of selenium. Selenium species enter the air due to combustion of coal. The selenium that remains in coal ash is predominantly in the toxic and water soluble selenite form. It is subject to sorption to various components of ash, though is generally mobile into the aqueous phase at acidic pH [24]. Waste water from coal mining operations may contain more than $1 \mathrm{mg}$ $\mathrm{L}^{-1}$ of selenium [23]. Problems with Se (and other pollutants due to processing and burning of coal) are a particular concern in China, where coal production and use have more than doubled since 2000 and are predicted to continue to rise, while they have been stable in most other areas of the world [25]

Other emerging industries may provide new sources of potentially harmful selenium exposure. Selenium is a significant element in waste electronic and electrical equipment (e-waste). One study in West Africa (Ghana) found a doubling in blood selenium concentration (together with a tripling of mercury levels) in workers involved in incineration of e-waste [26].

As detailed in the main text, methanotrophs and other environmental bacteria have the capacity to produce Se (0)-containing nanoparticles. In addition to being valuable in detoxifying selenium contamination and in providing novel nanoparticles for use in electronics, such nanoparticles may find uses as slow-releasing selenium supplements for diets [27].

bioaccumulate metals from the environment [1]. In particular, microorganisms possess remarkable abilities to bioaccumulate, retain and transform heavy metal ions [40-42] by taking advantage of reduction/ oxidation (redox) and other processes e.g. modulating solubility of metals without changing the oxidation state of the metal $[43,44]$.

Metal(loids) exhibit different physical and chemical forms (i.e. differences in speciation) in the environment. Electronic configuration, oxidation state and ionic radius all define the chemical speciation of a particular metal and its fractionation (i.e. whether it is labile/inert, ligand complexed, precipitated or existing as a free ion). Consequently, the chemical form of a metal strongly influences its reactivity, toxicity, mobility and interaction with microorganisms in the environment $[44,45]$. For instance, copper $(\mathrm{Cu})$ becomes potentially toxic when it transitions between $\mathrm{Cu}(\mathrm{II})$ and $\mathrm{Cu}(\mathrm{I})$, soluble and toxic chromium $(\mathrm{Cr}(\mathrm{VI}))$ are less toxic when reduced to $\mathrm{Cr}(\mathrm{III})$, mercury 
Table 3 Mercury pollution from artisanal/small scale gold mining

Mercury emissions from artisanal and small scale gold mining, estimated at 727 tonnes per annum, account for a large portion of emissions from anthropogenic sources (37\% [28];). Telmer and colleagues also estimated the contribution of artisanal and small scale gold mining to mercury releases between 640 and 1350 tonnes per year from at least 70 countries, with at least 350 tonnes emitted directly into the atmosphere while the remainder are released into the rivers, lakes, soil and tailings [29]. In small developing countries such as Guyana (Fig. 4), the gold mining industry is economically significant, where it contributed $13.7 \%$ to the total GDP of the country and accounted for more than $60 \%$ of total exports (USD 817.5 million) in 2017 [30]. The artisanal, small and medium scale operators, who contribute approximately two thirds of total gold declarations, rely almost exclusively on the use of mercury for gold extraction and concentration while the large scale companies utilise higher-recovering technologies with more control over environmental and safety risks [31]. Mercury is often added to the collected unprocessed gold ore in order to create a mercury-gold amalgam which is then heated to release the mercury and recapture the gold in concentrate. Most of the mercury vapour generated during burning of the amalgam may be collected by a retort, thus reducing mercury emissions by over $93 \%$. However, studies in Guyana and Suriname have shown that while miners have some knowledge of the negative health and environmental effects of burning amalgams in the open air, they do not regularly use retorts for a variety of reasons, with the most common cited as the retorts being 'too time-consuming' [32, 33].

In addition, mercury is sometimes used in sluice boxes and in panning which can also contaminate tailings, creeks and rivers which will leach into the surrounding environment. In the Minamata Initial Assessment conducted for Guyana, over 11,000 kg of mercury is estimated to be emitted annually in Guyana by burning of a mercury-gold amalgam, with 39\% released in the air, 32\% in water and 29\% in land [33]. Mercury emitted to the atmosphere can be deposited into aqueous environments by wet and dry depositions, and some can be re-emitted into the atmosphere. In surveys carried out by the Guyana Geology and Mines Commission (2000 and 2001) in three rivers within two different mining regions of Guyana, it was found that 57\%, 39\% and 25\% of predatory fishes sampled had mercury levels above the maximum World Health Organization guideline concentration $(0.5 \mu \mathrm{g} / \mathrm{g})$. Data from neighbouring Suriname and French Guiana, where mercury use in mining is also abundant, also indicate high levels of mercury contamination in fish [34]. In a study by Howard and colleagues, sediments taken from active and historically mined areas in Guyana had a mean mercury concentration of $0.229 \mu \mathrm{g} / \mathrm{g}$, with a range from 0.029 to $1.2 \mu \mathrm{g} / \mathrm{g}$, which is above Canadian Environmental quality guidelines $(0.19 \mu \mathrm{g} / \mathrm{g})$ [35]. There is also a lack of extensive data on mercury contamination in communities surrounding mining activities in Guyana. A study conducted from 2008 to 2010 by Singh and colleagues reported mercury concentrations of up to $70.8 \mu \mathrm{g} / \mathrm{g}$ (well over the WHO safe limit of $10 \mu \mathrm{g} / \mathrm{g}$ ) in the hair of pregnant and nursing women from indigenous populations living close to small scale gold mining activities [36].

Mercury has a long history of uncontrolled use in the mining sector of Guyana resulting in significant environmental pollution of waterways and aquatic ecosystems. The Government of Guyana has, however, signed the Minamata Convention and has subsequently aimed to phase out the use of mercury by 2022, with particular attention to the gold mining sector as part of this commitment. However, it has witnessed resistance by small miners who have not been able to adapt to other techniques as there is general lack of awareness and understanding of these technologies, along with a lack of fiscal incentives and barriers to accessing finance to transition from this cheaper alternative $[31,33,37]$.

$(\mathrm{Hg}(\mathrm{II}))$ becomes neurotoxic when its methylated $\left(\mathrm{CH}_{3} \mathrm{Hg}\right)$ and $\mathrm{As}(\mathrm{III})$ is more toxic than $\mathrm{As}(\mathrm{V})$ [46-48].

Recent research has highlighted the ability of aerobic methanotrophs, a specialised group of bacteria that can use methane $\left(\mathrm{CH}_{4}\right)$ as a sole carbon and energy source, to transform metals (and also metalloids) such as $\mathrm{Cu}$, $\mathrm{Cr}$, Se and Hg [41, 49, 50]. Methanotrophs belong to the phyla Proteobacteria (classes Alphaproteobacteria and Gammaproteobacteria), Candidate division NC10 and Verrucomicrobia. Till date, more than 29 methanotroph genera and 8 families (i.e. Methylococcaceae, Methylothermaceae, Crenotrichaceae, Methylocystaceae, Beijerinkiaceae, and Methylacidiphilaceae and two currently unclassified families) have been identified within these phyla. Complete genome sequences for representatives of $>23$ genera are available in public repositories [51, 52]. Proteobacterial methanotrophs are active primarily in methane-oxygen counter gradients of oxic-anoxic interfaces [and in upland soils (high affinity atmospheric methane oxidisers)], while methanotrophs found in extremely acidic geothermal sites belong to the phylum Verrucomicrobia. Anaerobic microbial methane oxidation has been recently discovered that use reverse methanogenesis process to convert $\mathrm{CH}_{4}$ into $\mathrm{CO}_{2}[53,54]$. In contrast, the members of the candidate phylum $\mathrm{NC10}$, such as Candidatus Methylomirabilis oxyfera, use all aerobic methane oxidated pathway-specific proteins, while it acquires oxygen through reduction of nitrite to the oxidation of methane via a unique oxygen-producing pathway [55]. The activity and diversity of methanotrophs and their impact on methane fluxes in different environments (e.g. landfills, rice paddies, natural gas seeps, hypogenic caves, saline lakes) have been studied extensively using both cultivation-dependent and molecular ecology tools [56-59]. In this review, we focus on recent developments in the physiology of aerobic methanotrophs with emphasis on their role in transformation and speciation of metals and metalloids such as $\mathrm{Cu}, \mathrm{Cr}$, $\mathrm{Se}$ and $\mathrm{Hg}$. Detailed descriptions of the biochemistry and physiology of methanotrophs/methylotrophs are beyond the scope of this review and the reader is referred to $[5,60]$.

\section{Aerobic methane oxidation and metalloenzymes}

In aerobic methanotrophs, four major steps are involved in the enzymatic conversion of $\mathrm{CH}_{4}$ into biomass $/ \mathrm{CO}_{2}$, in which the availabilities of different metal ions play a critical role (Fig. 1). The biocatalytic oxidation of $\mathrm{CH}_{4}$ to methanol $\left(\mathrm{CH}_{3} \mathrm{OH}\right)$ is modulated by the enzyme methane monooxygenase (MMO). Two forms of MMO exist: membrane-bound particulate MMO (known as pMMO and its divergent form pXMO [61]) and cytoplasmic soluble MMO (sMMO).

(a) $\boldsymbol{p} \boldsymbol{M M O}$ composed (i) $\beta$-subunit, PmoA (26 kDa); (ii) $\alpha$-subunit, $\operatorname{PmoB}(45 \mathrm{kDa})$; and (iii) $\gamma$-subunit, PmoC $(23 \mathrm{kDa})$ with an $(\alpha \beta \gamma)_{3}$ structure. Their genes are typically arranged in pmo-operons as 


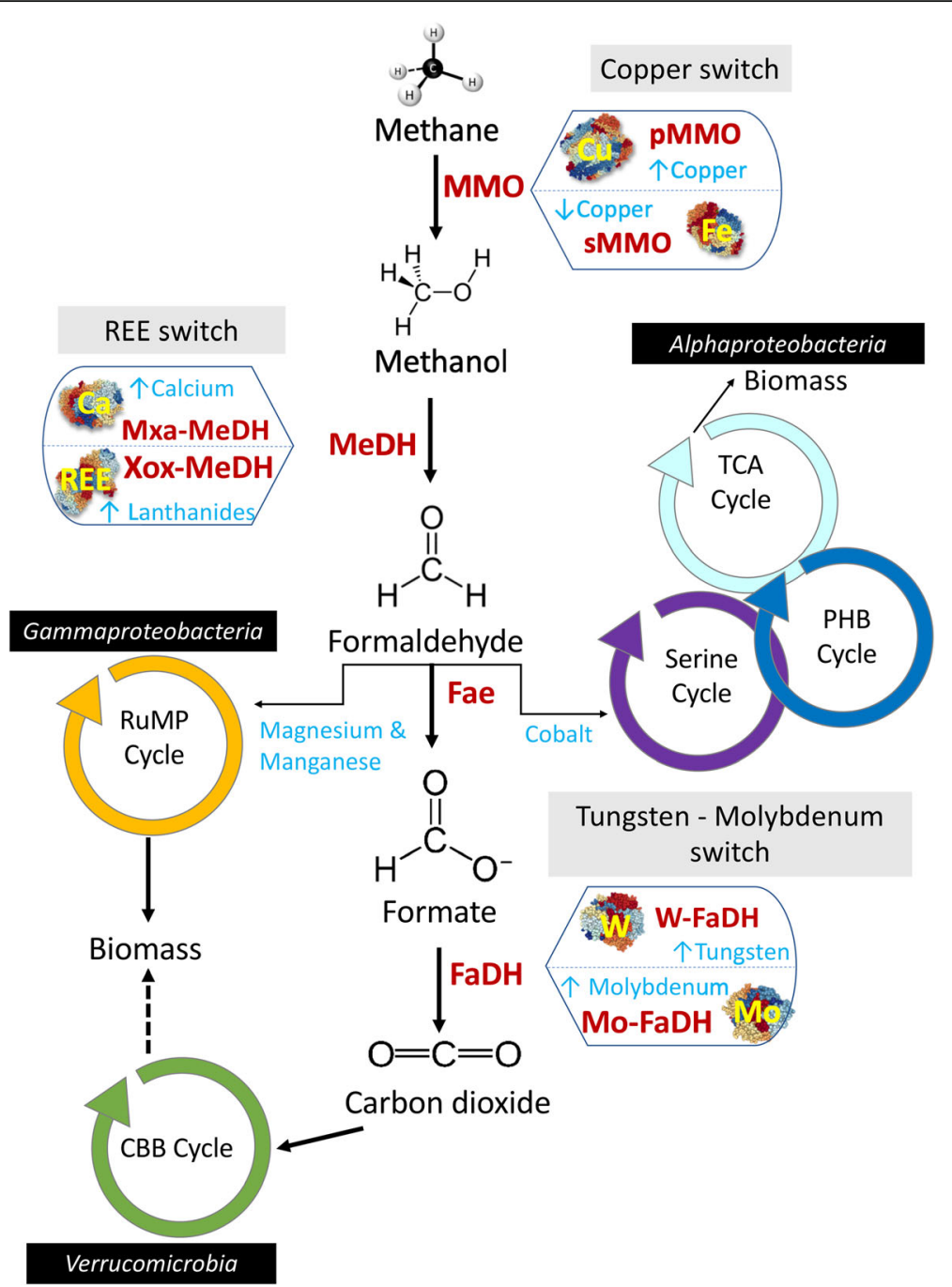

Fig. 1 Methane oxidation by aerobic methanotrophs and metal co-factors of the enzymes. $\mathrm{pMMO}=$ particulate methane monooxygenase. sMMO = soluble methane monooxygenase. Xox-MeDH = XoxF-methanol dehydrogenase. Mxa-MeDH = MxaFI-methanol dehydrogenase. Fae = formaldehyde activating enzyme. FaDH = formate dehydrogenase. $\mathrm{CBB}=$ Calvin Benson Bassham Cycle. RuMP = Ribulose MonoPhosphate cycle. TCA - The Citric Acid cycle. PHB - Polyhydroxybutyrate cycle. Enzymes modulating the reaction are represented in red font, metals in blue \& yellow fonts. Small vertical light blue arrows next to each metal ion indicate their effect on the expression and/or activity of enzymes

pmoCAB. Th general hypothesis is that the enzyme pMMO obtains electrons from the cytochrome $b c 1$ complex, which contains heme groups and $\mathrm{Fe}_{2} \mathrm{~S}_{2}$ clusters [62, 63]. It has been proposed that $\mathrm{Fe}$ is required for pMMO activity [63], although a recent study shows only the presence of two mono-copper sites [64]. However, the alphaproteobacterial pMMO acquires electrons from ubiquinone pool through NADH oxidation $[65,66]$, while the pMMO activity in gammaproteobacterial methanotrophs is reported to be coupled to the oxidation of methanol to formaldehyde [67].

(b) $\boldsymbol{s M M O}$ is a well-characterised three-component enzyme: (i) hydroxylase contains 3 sub-units $(\alpha: \beta: \gamma$ - 54: 42: $22 \mathrm{kDa}$, respectively) with an $(\alpha \beta \gamma)_{2}$ structure; (ii) reductase $(38-40 \mathrm{kDa})$ that supplies electrons from NADH to the hydroxylase; and (iii) component $\mathrm{B}$ as a regulatory protein $(15-17 \mathrm{kDa})$ [68-70]. The sMMO is encoded by mmoXYBZDC. It contains a di-iron active site cluster in the hydroxylase component as well as an $\mathrm{Fe}_{2} \mathrm{~S}_{2}$ cluster and flavin adenine dinucleotide (FAD) moiety in its reductase component [52].

The two types of MMO differ completely in their metal ion requirements, substrate specificity and $\mathrm{CH}_{4}$ oxidation kinetics [52, 64, 70-72]. Specifically, $\mathrm{Cu}$ (II) to biomass ratio determines the expression and activity of MMOs in methanotrophs that can express either form of the enzyme and is often referred to as the copper 
switch' [52, 61, 72-74]. Most aerobic methanotrophs possess pMMO or pXMO (with exceptions of alphaproteobacterial members within the genera Methylocella, Methyloceanibacter and Methyloferula), while few possess both pMMO and sMMO (e.g. Methylosinus spp., Methylocystis spp., Methylobacter marinus, Methylocaldum marinum, Methylococcus capsulatus, Methylomagnum ishizawai 175, Methylomicrobium buryatense 5G, Methylovulum miyakonense HT12, Methylomonas spp. [52, 75-77];). A very few methanotrophs e.g. Methylocella spp., Methyloferulla spp., Methyloceanibacter spp., (Alphaproteobacteria) and Methyloterricola spp. (Gammaproteobacteria) contain only sMMO (Vekeman et al., 2016; Semrau et al., 2018). The methane turnover number per active site cells producing pMMOs (0.5-2.5 $\mathrm{s}^{-1}$ ) are comparatively lower than sMMO expressing cells $\left(>3.5 \mathrm{~s}^{-1}\right)[70]$.

In the second step, methanol is converted into formaldehyde by the enzyme methanol dehydrogenase $(\mathrm{MeDH})$, which contains a pyrroloquinoline quinone (PQQ) cofactor. There are two distinct types of MeDH, (a) calcium dependent $\mathrm{MeDH}$ (i.e. $\mathrm{MxaF}-\mathrm{MeDH}$ ) or (b) the recently discovered XoxF, which is an $\mathrm{MeDH}$ dependent on rare earth elements (REEs) e.g. cerium or lanthanum [5, 78-82].

(a) $\mathbf{M x a F - M e D H}$ is tetrameric $\left(\alpha_{2}-66 \mathrm{kDa} ; \beta_{2}-8.5\right.$ $\mathrm{kDa})$, with greatest activity at $\mathrm{pH} \sim 9$ and requiring activation (e.g. by ammonia [83, 84];). The $\alpha$ subunit contains a single $\mathrm{Ca}^{2+}$ ion, the coordination sphere of which contains one nitrogen and two oxygen ligands from PQQ and a further four oxygen ligands from three aminoacyl sidechains (Glu 205, Asn 289 and Asp 331) [85].

(b) $\mathbf{X o x F - M e D H}$ is a $\alpha 2$ homodimer, located in the periplasm and active at neutral $\mathrm{pH}$ (optimum $\sim 7$ ). It coordinates the REE at the active site in a 9coordinate fashion, via the same three ligands from PQQ and six oxygen ligands derived from four amino acyl residues (Glu 197, Asn 285, Asp 327 and Asp 329) of the protein [86]. It has been reported that the activity of purified XoxF was higher with light REEs (atomic numbers 57-63; La-Eu) in comparison to heavy REEs (atomic numbers 64-71; Gb-Lu) [87].

It should be noted that XoxF-MeDHs are also present in yeast, moulds, fungi and non-methylotrophic bacteria [88]. In methanotrophs such as Methylomagnum ishizawai 175, Methylomicrobium kenyense AMO1, Methyloterricola oryzae 73a, Methylocystis sp., Mit Z-2018, Methylosinus spp., R-45379, Methyloacidiphilum fumariolicum SolV and Verrucomicrobium spp., the only form of $\mathrm{MeDH}$ that have been identified is the XoxF-MeDH.
The physiology and genetic basis of the 'REE-switch' that controls expression of the alternate forms of $\mathrm{MeDH}$ is reviewed extensively in $[5,52]$. XoxF-MeDH is reported to have higher affinity for methanol and faster conversion rate [89]. While there was an assumption that XoxF-MeDH oxidises methanol to formate by dual activity [90, 91], a recent study by Good and Colleagues [92], using XoxF purified from Methylobacterium extorquens AM1, confirmed that formaldehyde is the final product. There are 5 families of XoxF-MeDH that might display different catalytic properties [93], while all need to be validated to conclude whether the dual activity is relevant in vivo or not.

In subsequent steps, the formaldehyde derived from the oxidation of methanol is assimilated as biomass either via the ribulose monophosphate pathway (RuMP) in most of Gammaproteobacteria or the serine pathway in Alphaproteobacteria. There are multiple pathways for oxidation of formaldehyde to $\mathrm{CO}_{2}$ i.e. in conjugation with tetrahydromethanopterin $\left(\mathrm{H}_{4} \mathrm{MPT}\right)$ or tetrahydrofolate $\left(\mathrm{H}_{4} \mathrm{~F}\right)[94]$.

\section{(a) The multi-step $\mathrm{H}_{4} \mathrm{MPT}$ - and $\mathrm{H}_{4} \mathrm{~F}$-dependent} pathways, which also exist in non-methanotrophic methylotrophs such as Methylobacterium extorquens, operate by conjugating the formaldehyde and subsequent intermediates with the respective coenzymes. In model methanotrophs such as $M c$. capsulatus (Bath) and Ms. trichosporium, OB3b studies have shown the use of both $\mathrm{H}_{4} \mathrm{MPT}$ - and $\mathrm{H}_{4} \mathrm{~F}$-dependent pathways [95-98].

(b) $\boldsymbol{D L}$-FalDH is homotetramer with a sub-unit mass of $\sim 49 \mathrm{kDa}$, while the sub-unit contains a PQQ as red-ox co-factor at 1:1 ratio. It utilises cytochrome $b_{559 / 569}$ complex as a electron acceptor [99].

(c) $\boldsymbol{N}$-FalD $\boldsymbol{H}$ was reported as an $\mathrm{NAD}(\mathrm{P})^{+}$-linked dehydrogenase from Mc. capsulatus (Bath) where the ability to oxidise formaldehye depended on a low molecular-mass heat-stable component $[100,101]$. Later attempts to replicate these results yielded preparations that were active but found to be mixtures of other enzymes and cofactors involved elsewhere in the methane oxidation pathway [102]. Hence, whether an enzyme that directly catalyses $\mathrm{NAD}(\mathrm{P})^{+}$-linked oxidation of formaldhyde is a substantial contributor to the aerobic methane oxidation pathway remains unclear.

However, cytochrome $b c 1$ (with $\mathrm{Fe}$ ) is required for FalDH as an electron acceptor. Also, other enzymes involved in the conversion of methanol into formaldehyde, formate and finally into carbon dioxide primarily rely on 
$\mathrm{Fe}$, with minor requirements of $\mathrm{Cu}, \mathrm{Ca}, \mathrm{Mo}$ and Zinc $(\mathrm{Zn})$ ions. In particular, the membrane-associated formate dehydrogenase ( $\mathrm{FaDH})$ enzyme, which is $2 \alpha \beta \gamma \delta$ protomers $(\mathrm{Mw} \sim 400 \mathrm{kDa})$. The holoenzyme contains flavin, iron, inorganic sulphide and molybdenum [103]. The $\mathrm{FaDH}$ is involved in the conversion of formate to $\mathrm{CO}_{2}$, contains four $\mathrm{Fe}_{\mathrm{x}} \mathrm{S}_{\mathrm{x}}$ clusters and molybdenum (Mo) as cofactors [62]. Recently, the presence of two clusters encoding $\mathrm{NAD}^{+}$-dependent $\mathrm{FaDH}$ that require either tungsten (W) or Mo was reported [90]. Moreover, it was also observed that in Methylomicrobium alcaliphilum 20ZR formate production was considerably reduced during the presence of $\mathrm{W}$ [90]. Further work is required to develop a better understanding of whether a 'W-Mo switch' regulates expression of the two types of $\mathrm{FaDH}$.

\section{Metal uptake mechanisms in aerobic methanotrophs}

Metal ions are integral to metabolic activities (Table 4) in methanotrophs. It has been estimated that about one quarter to one third of any bacterial cell proteins required metal ions to support their functions [104]. However, cells can restrict the number of metal ions to be transported into their cytoplasm, thereby creating a competition between different proteins requiring the same metal ions and thus influencing different enzyme activities in vivo. Specific energised pumps are used to facilitate metal ion transport either into the cell (importers) or out of it (exporters). Such transporters are generally located in the cell membrane and may use selective metal binding proteins or small molecules such as siderophores [105]. In methanotrophs, metals are transported into the cell by (a) passive diffusion e.g. direct transport through porins in surface membrane and/or (b) active transport e.g. through TonB-dependent metal transport or other metal transport proteins $[106,107]$.

\section{Passive diffusion of metals}

Passive transport of metals and organic solutes usually occurs via porins. The pore size and amino-acid compositions in the channel of porins determine their specificity towards different solutes and transport. In bacteria, the performance of porins (both non-specific and specific diffusion channels) is usually regulated by the availability of specific nutrients and downregulated by the presence of toxins or harmful solutes [108]. Based on their structure and diffusion characteristics, porins are classified as (a) specific monomeric, (b) specific trimeric, (c) non-specific monomeric and (d) non-specific trimeric diffusion channels [109], while little is known about the porin structures in methanotrophs. Reseachers have characterised a small number of outer membrane proteins (e.g. MopE and CorA) that can perform the function of copper transport in methanotrophs [106]. While MopE (some methanotrophs from Gammaproteobacteria express it) has been reported to bind copper with high affinity $\left(<10^{20} \mathrm{M}^{-1}\right)$ and to have a binding site composed of two imidazoles and a kynurenine (modified tyrptophan side-chain) group [110], other outer membrane proteins, as wells as their arrangements are yet to be characterised in detail. Unchelated metal ions are also reported to be transported via porins e.g. $\mathrm{Cu}$ and $\mathrm{Hg}$ transport in M. album BG8 [50].

\section{Active transport of metals}

It has been reported that about $10^{-6} \mathrm{M}$ of intracellular ion concentration is required for any cellular activity and at lower levels, metal binding proteins or small molecules (e.g. siderophores) are synthesised by bacteria (including methanotrophs) to scavenge metals from the environment. For example, methanotrophs produce methanobactin under $\mathrm{Cu}$ limited conditions [111, 112]. Methanobactin, a chalkophore (chalk - copper in Greek), is a ribosomally produced and posttranslationally modified peptide [72, 111, 113]. It plays a key role in active transport of metals and perhaps also enables ecological succession of different methanotrophs under external metal toxicities [72]. Specifically, the methanotrophs can export up to 3-50 methanobactin molecules per cell per second dependent on the $\mathrm{Cu}$ concentrations in the external solute [72]. Only very few methanotrophic species from the Alphaproteobacteria family are reported to biosynthesise methanobactin and only $10 \%$ of sequenced methanotrophs contain methanobactin biosynthesis genes [72, 74, 114]. Methanobactins produced by different methanotrophs are structurally distinct (i.e. till date only 7 methanobactins are characterised from methanotrophs), though with

Table 4 Redox states of metals with metallo-enzymes and their specific catalytic functions

\begin{tabular}{|c|c|c|c|}
\hline Metal & Redox state & Enzymes & Class of catalysis by enzyme \\
\hline Copper & $\mathrm{Cu}(\mathrm{II}), \mathrm{Cu}(\mathrm{I})$ & Most copper-containing enzymes (e.g. Cytochromes) & Electron transfer, ferrous oxidase, amine oxidase \\
\hline Iron & $\begin{array}{l}\text { Fe (III), Fe (III), } \\
\text { Fe (IV), Fe (V) }\end{array}$ & $\begin{array}{l}\text { Cytochromes } \\
\text { Peroxidase, catalase }\end{array}$ & Electron transfer, Oxidation \\
\hline Molybdenum & Mo (III) to Mo (VI) & Nitrogenase, Aldehyde oxidase & Oxidation \\
\hline Cobalt & Co (I)?, Co (II), Co (III) & B12- requiring enzymes & Carbonic anhydrase \\
\hline Manganese & $\mathrm{Mn}(\mathrm{III})$ to $\mathrm{Mn}(\mathrm{IV})$ ? & Photosynthetic enzymes & Superoxide dismutase, oxidase \\
\hline Chromium & $\mathrm{Cr}(\mathrm{VI})$ to $\mathrm{Cr}(\mathrm{III})$ & Dehydrogenase & Oxidoreductases \\
\hline
\end{tabular}


similar metal (i.e. $\mathrm{Cu}$ ) binding sites, and are categorised as Group-I and II (Table 5). Ms. trichosporium OB3b was reported to produce the highest concentrations of Group-I methanobactin (35-60 $\mathrm{mg} \mathrm{l}^{-1}$ ) followed by the Mc. capsulatus (Bath) (18-24 $\mathrm{mg} \mathrm{l}^{-1}$ ) [115]. Interestingly, Mc. capsulatus (Bath) does not have the $m b n$ cluster encoding methanobactin production $[116,117]$ indicating a different type of copper-binding molecule (including but possibly not restricted to MopE [118] used in high-affinity copper acquisition). Group-II methanobactin is mainly produced by Methylocystis sp. strain SB2, while recent bioinformatic analysis has shown that there are few methanotrophs that can make both the forms of methanobactins e.g. Methylocystis parvus OBBP, Methylocystis sp. LW5, Methylosinus sp. LW3, Methylosinus sp. R-45379 and Methylosinus sav2 [112].

As discussed earlier, methanobactin is reported to show high affinity towards $\mathrm{Cu}\left(\sim 10^{11}\right.$ to $\left.10^{34} \mathrm{M}^{-1}\right)$ followed by $\mathrm{Ag}\left(\sim 10^{7} \mathrm{M}^{-1}\right)$ as summarised in Fig. 2 . Based on the metal binding properties of methanobactin, metals are grouped under two categories: Group A metals- $\mathrm{Ag}(\mathrm{I}), \mathrm{Au}(\mathrm{III}), \mathrm{Hg}(\mathrm{II}), \mathrm{Cu}(\mathrm{II})$ and $\mathrm{Pb}(\mathrm{II})$ and Group B metals-Cd(II), Co(II), Fe(III), Mn(II), Ni(II) and $\mathrm{Zn}(\mathrm{II})$ [118]. Group A metals bind at both oxazolone rings and are reduced upon binding, while Group B metals bind at just one oxazolone ring and are not reduced upon binding $[118,119]$. Based on the methanobactic metal selectivity, the metals are grouped as (a) Group-1 (high-100\%): Cu (I) and Ag (I); (b) Group 2 (moderate-85-96\%): Zn (II), Ni (II) and Co (II); and (c) Group 3 (low-<50\%): Mn (II), $\mathrm{Pb}$ (II) and $\mathrm{Fe}$ (II).
Studies have also shown that the methanobactin can also bind, transform and detoxify $\mathrm{Hg}[50,69,120]$ and $\mathrm{U}(\mathrm{VI})$ [121]. In a recent study, a methanobactin characterised from Methylosinus sporium was found to have one oxazolone and one imidazolone ring with disulphide bond between two Cys residues as in Group 1 [116]. The structural difference may affect the metal binding and affinity, which is not completely understood yet. So the classification, metal affinity and grouping of metals described above may applicable only to the methanobactins from Methylosinus trichosporium OB3b and Methylocystis sp. strain SB2, while it may vary for other methanobactin structures and requires further investigation. This knowledge is critical in determining how to exploit methanotroph strains and/or methanobactins to sequester the metal ions from the environment.

\section{Copper accumulation by methanotrophs}

Copper is central to methanotrophic activity, while 40\% of methanotrophs are reported to have $\mathrm{Cu}$ storage proteins and only $10 \%$ reported to make methanobactins for $\mathrm{Cu}$ uptake, while the remainder may use passive transport of metals using other porin related proteins [122]. It has been estimated that methanotrophs have at least a ten-fold greater $\mathrm{Cu}$ requirement compared with other bacteria [123]. While $\mathrm{Cu}$ is an essential metal ion for pMMO activity (i.e. $\mathrm{CH}_{4}$ to methanol conversion), it has also been shown to control expression of other enzymes (e.g. formaldehyde dehydrogenases, hemerythrin) and outer membrane proteins involved in $\mathrm{Cu}$ assimilation, regulation and transport. Moreover, it can influence the

Table 5 Difference between two well characterised known groups of methanobactins

\begin{tabular}{|c|c|c|}
\hline Particulars & $\begin{array}{l}\text { Group } 1 \text { methanobactin } \\
\text { (e.g. Ms. trichosporium OB3b) }\end{array}$ & $\begin{array}{l}\text { Group } 2 \text { methanobactin } \\
\text { (e.g. Methylocystis strain SB2) }\end{array}$ \\
\hline Molecular weight (Da.) & 1154.26 & 851.20 \\
\hline Structural difference & $\begin{array}{l}\text { Two oxazolone rings (UV-vis spectra: Ring A } \\
394 \mathrm{~nm} \text { and } \mathrm{B} \sim 342 \mathrm{~nm} \text { ) }\end{array}$ & $\begin{array}{l}\text { One oxazolone ring (UV-vis spectra: Ring B 338nm) and } \\
\text { Imidazolone (UV-vis spectra: Ring A } \sim 387 \mathrm{~nm})\end{array}$ \\
\hline $\begin{array}{l}\text { Partial amino-acids associ- } \\
\text { ated with Ring-A }\end{array}$ & Leucine & Arginine \\
\hline $\begin{array}{l}\text { Partial amino-acids associ- } \\
\text { ated with Ring-B }\end{array}$ & Proline & Threonine \\
\hline Amino acids & $\begin{array}{l}\text { Gly }^{1}, \text { Ser }^{2}, \text { Cys }^{3}, \text { Tyr }^{4}, \text { Ser }^{5}, \mathrm{Cys}^{6} \text { and } \mathrm{Met}^{7}\left(\mathrm{Gly}^{1}-\right. \\
\text { Downfield shift at } 9.28 \mathrm{ppm})\end{array}$ & $\mathrm{Ala}^{1}, \mathrm{Ser}^{2}, \mathrm{Ala}^{3}, \mathrm{Ala}^{4}$ (Ala ${ }^{1}$ - Downfield shift at 11.7 and 145 ppm) \\
\hline Copper affinity & $10^{18}-10^{50} \mathrm{M}^{-1}$ & $10^{26} \mathrm{M}^{-1}$ \\
\hline Copper binding Ring-A & $640 S^{-1}$ & Not available \\
\hline $\begin{array}{l}\text { Copper co-ordination rate } \\
\text { with Ring-B }\end{array}$ & $121 \mathrm{~S}^{-1}$ & $>2000 \mathrm{~S}^{-1}$ \\
\hline Structure modification & Pyramid-like structure & Hairpin-like structure \\
\hline Stability & $\begin{array}{l}\text { Both rings hydrolysed within } 2-5 \text { days under } \\
\text { acidic condition }\end{array}$ & $\begin{array}{l}\text { Ring B (i.e. Oxa) is susceptible to hydrolysis (200 min) and Ring-A } \\
\text { more resistance }\end{array}$ \\
\hline Disulphide bond & Found & Not found \\
\hline Sulphate group & Not found & Found \\
\hline
\end{tabular}

Note: Da. daltons, UV ultraviolet, Gly glycine, Ser serine, Cys cystine, Tyr tyrosine, Met methionine, ppm parts per million 


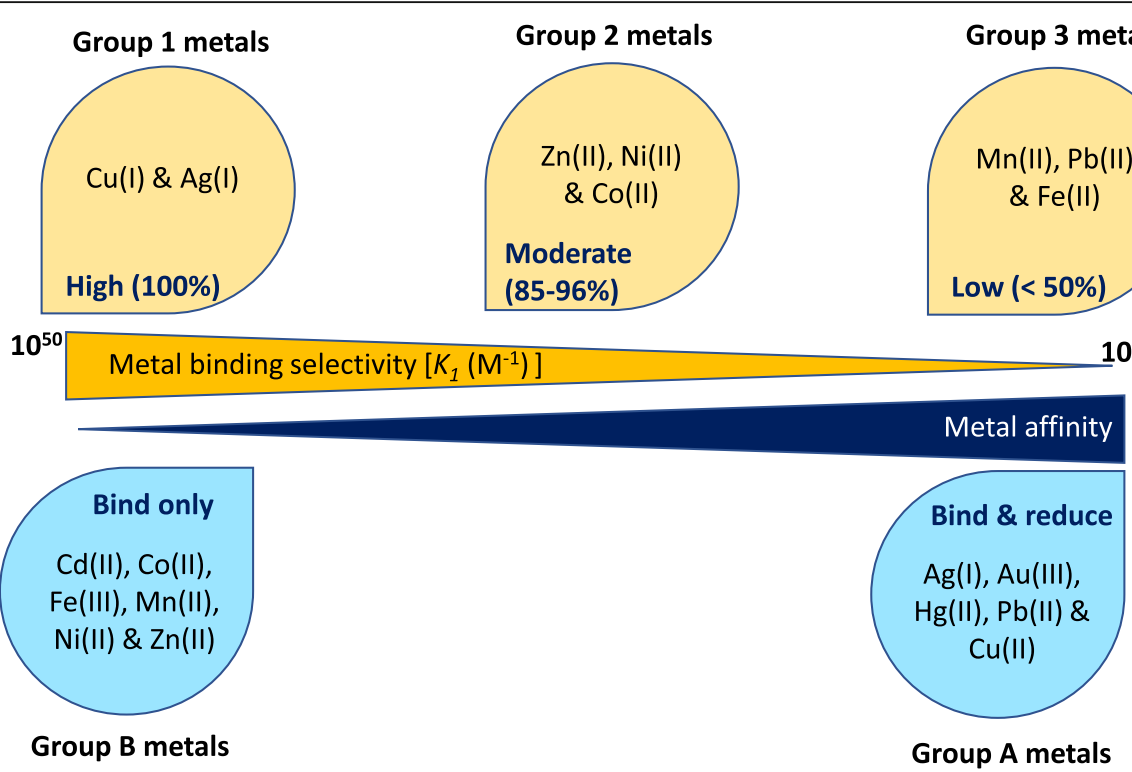

Fig. 2 Grouping of metals based on their affinity and selectivity with methanobactin

membrane structure or formation in methanotrophs e.g. M. capsulatus (Bath), M. album BG8 and Ms. trichosporium OB3b [123, 124]. The Cu-containing protein pMMO, which constitutes up to $20 \%$ of the total cellular proteins in methanotrophs [125] shows high-affinity towards $\mathrm{CH}_{4}$. The pMMO is expressed at high $\mathrm{Cu}$ concentrations, and at low levels, sMMO is expressed [126]. At high $\mathrm{Cu}$ concentrations, the $\mathrm{Cu}$ will bind the active site of sMMO and inhibit the electron transfer between the falvin adenine dinucleotide and $\mathrm{MMOH}$ [127]. High copper-to-biomass ratio leads to pMMO expression through the canocial 'copper switch', but the exact mechanisms by which $\mathrm{Cu}$ activates pMMO expression is not yet clear. However, the rate of copper uptake by passive diffusion or active transport may differ between methanotrophs, mainly in Alphaproteobacteria and Gammaproteobacteria. During active transport, divalent $\mathrm{Cu}$ is reduced to monovalent $\mathrm{Cu}$, which forms a more stable complex with methanobactin that will not be disassociated by simple dissolution mechanisms and transport into the cell. The methanobactin-Cu (I) complexes (at 1:1 stochiometry [119];) are reported to be too large to be transported via porins, and their transport is mainly mediated by outer membrane TonB-dependent transporters (TBDTs [106, 107];). However, it should be noted that the mechanism of $\mathrm{Cu}$ reduction by methanobactin is still unknown [111], while $\mathrm{Cu}$ concentrations and $\mathrm{pH}$ are known to influence the metal-methanobactin interactions [115, 128]. The methanobactin- $\mathrm{Cu}$ complex is also reported to regulate reductase-dependent oxidase activity, dismutation of $\mathrm{O}_{2}$ to $\mathrm{H}_{2} \mathrm{O}_{2}$, and the reductant-dependent reduction of $\mathrm{H}_{2} \mathrm{O}_{2}$ to $\mathrm{H}_{2} \mathrm{O}$ [129]. Recently, researchers have characterised the novel Csp-proteins i.e. Csp1 and Csp2 that were reported to be a major reservoir for $\mathrm{Cu}$ (up to $13 \mathrm{Cu}(\mathrm{I})$ in one Csp protein molecule; affinity $\sim 10^{17} \mathrm{M}^{-1}$ ) and proposed to be exported from the cytosol to supply copper to pMMOs [130]. The related protein, Csp3, can hold upto 80 $\mathrm{Cu}(\mathrm{I})$ ions. Csp3 is speculated to sequester excess copper in the cytosol and rescue cellular activity from metal toxicity. Csp3, which also occurs in non-methanotrophs including Bacillus subtilis, is the only bacterial system known to store $\mathrm{Cu}$ in the cytoplasm [122]. The mechanism of $\mathrm{Cu}(\mathrm{I})$ release from the metallo-proteins methanobactin and the Csp is still not clear. Considering their copper requirements and ability to produce $\mathrm{Cu}$-binding proteins and peptides, methanotrophs could be potentially exploited for copper extraction and recovery from $\mathrm{Cu}$ ore, minerals and tailings or remediation of $\mathrm{Cu}$ contaminated sites using either whole cell or immobilised protein based approaches [131]. Existing bioleaching methods work effectively under acidic $\mathrm{pH}$ $(\sim 2.0)$, whereas methanotroph-based bioleaching could work effectively under neutral $\mathrm{pH}$ and thus be considered as more eco-friendly.

\section{Interaction of methanothrophs with chromium (VI)}

Chromium is found in the environment mainly in its two most stable oxidation states, the highly soluble, bioavailable and oxidising hexavalent form and the less toxic, less soluble and less bioavailable trivalent form [132]. Despite world-wide regulation of the use of hexavalent chromium in metal plating, to inhibit corrosion and as a wood preservative, among other applications, hexavalent $\mathrm{Cr}$ (VI) continues to be a substantial environmental problem. Chromium is heavily used in a number of industries, especially in the production of chromiumiron alloys such as stainless steel and the use of $\mathrm{Cr}$ (III) salts in leather manufacture (see Table 1 for case study 
on the extent of $\mathrm{Cr}$ pollution from tannery industries). In 2017, total production of chromium-iron alloys was 31 million tons. In which, $70-80 \%$ comes from South Africa (15 MT), Kazakhstan (5.4 MT), India (3.2 MT) and Turkey (2.8 MT), while China and the USA are the top consumers of $\mathrm{Cr}$ alloys. Anthropogenic $\mathrm{Cr}$ contamination contains a significant amount of $\mathrm{Cr}$ (VI) which may leach into the aqueous environment $[12,133]$.

A wide range of bacteria including methanotrophs have been found able to bioremediate $\mathrm{Cr}(\mathrm{VI})$ by reducing it to the less harmful trivalent form [134]. Among the well characterised methanotrophs, Methylococcus capsulatus (Bath) is able to reduce $\mathrm{Cr}(\mathrm{VI})$ over a wide range of concentrations (tested across 1.4 to $1000 \mathrm{mg}$ $\mathrm{L}^{-1}$ ), which offers the attractive possibility of using cheaply available methane to drive bioremediation of $\mathrm{Cr}(\mathrm{VI})$ and to sequester the $\mathrm{Cr}(\mathrm{III})$ product in the insoluble fraction, associated with the bacterial biomass (Fig. 3a). X-ray spectroscopy has confirmed that the $\mathrm{Cr}$ is in the +3 oxidation state and appears to have oxygen and phosphorous ligation [41]. Cell fractionation, together with in situ analysis of chromium distribution via $\mathrm{X}$-ray photoelectron spectroscopy (XPS) and transmission electron microscopy coupled to energy-dispersive
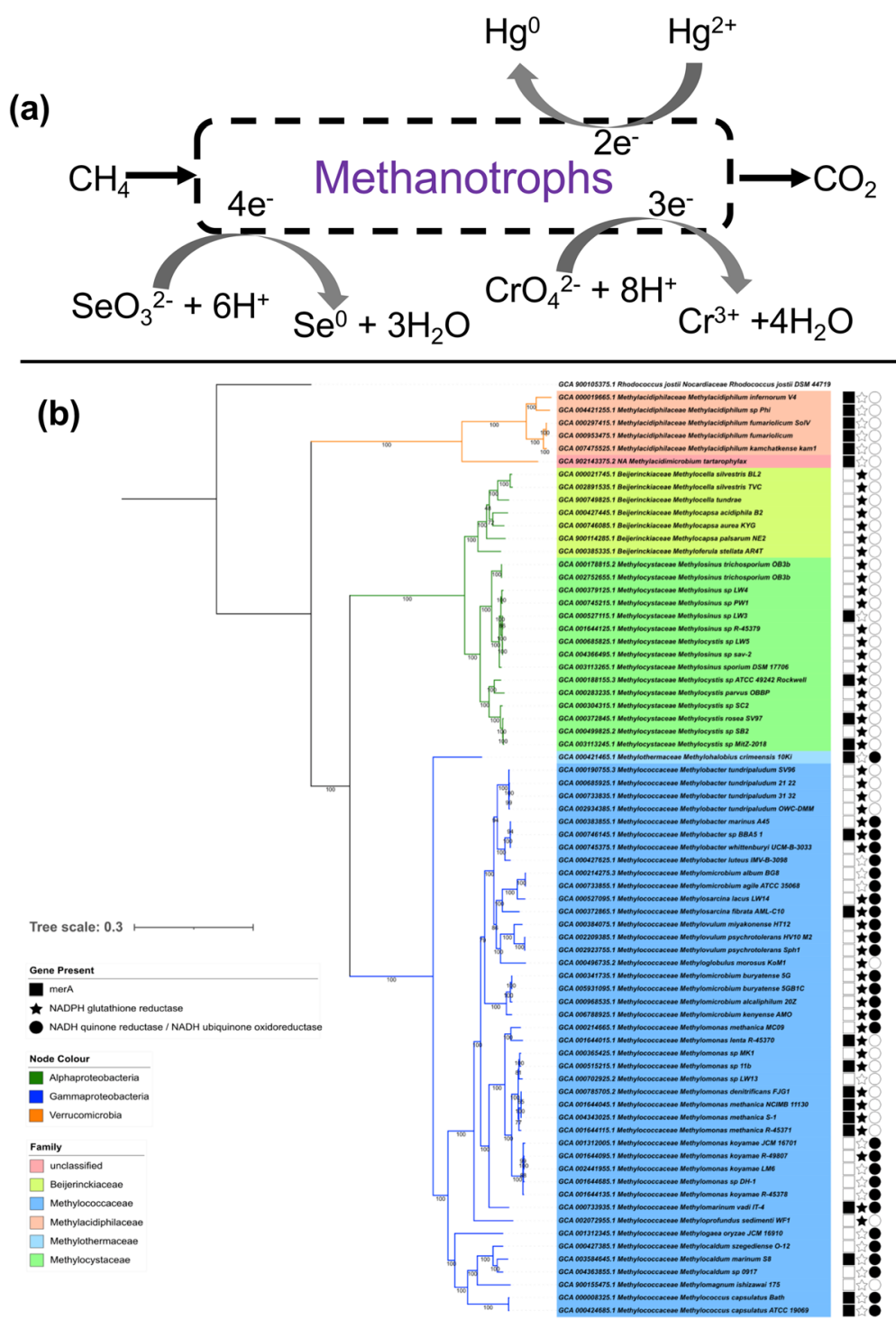

Fig. 3 a Pathways of methane-driven metal biotransformation by obligate aerobic methanotrophs. $\mathbf{b}$ Genomic distribution of potential biomarker genes involved in metal transformation in methanotrophs. Presence/absence of biomarker genes are mapped to a phylogenomic tree constructed using 74 single-copy marker genes specific to Bacteria via the GtoTree (v1.5.22) pipeline (as described in [135]). Protein sequences were retrieved using HMMER3 tool and multiple alignments were produced using MUSCLE (v.3.8.31, default settings). Conserved alignment blocks were identified using trimal (v1.4; -automated1 option) and subsequently used for tree construction using the IQTREE2 (v2.0.3) using default setting and 1000 boostraps 


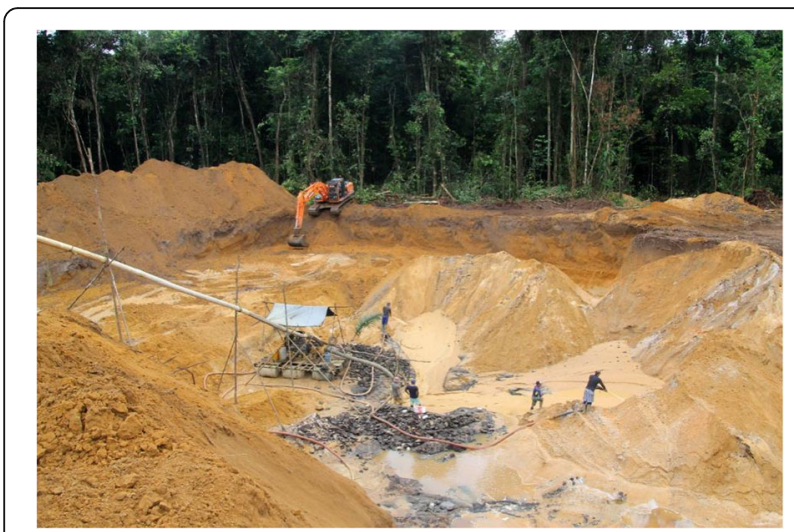

Fig. 4 A typical artisanal/small scale gold mining operation in Guyana

X-ray spectroscopy (TEM-EDX) showed that the chromium is predominantly intracellular [136]. Cells of the alphaproteobacterial methanotroph Ms. trichosporium did not reduce chromium (VI), although another gammaproteobacterial methanotroph Methylomonas koyamae SHU1, has been identified as able to reduce chromium (VI) [137]. Bioinformatic analysis of the genome of Mc. capsulatus (Bath) revealed five candidate reductases homologous to enzymes from other microorganisms known to reduce $\mathrm{Cr}(\mathrm{VI})$ [41]. Analysis of representatives of all methanotroph genera for which genome sequences is available indicates the presence of multiple potential chromium (VI) reductases in all of them. Comparative genomics of the three species for which the chromium (VI) reduction phenotype is known shows that only one homologue, a putative $\mathrm{Na}^{+}$-translocating NADHquinone reductase subunit $\mathrm{F}$ (locus tag MCA2384 in $M c$. capsulatus (Bath)), correlates with the ability to reduce chromium (VI) and so is a candidate for the chromium (VI)-reducing activity. This homologue is not found in any currently available alphaproteobacterial genomes and is present in 29 out of 44 gammaproteobacterial methanotroph genomes (Fig. 3b).

A mixed culture in a membrane biofilm reactor system was found able to reduce chromium during continuous operation (feeding at $1-3 \mathrm{mg} \mathrm{L}^{-1}$ of $\mathrm{Cr}(\mathrm{VI})$ ) with a microbial consortium that contained microorganisms of the genera Meiothermus and Methylosinus. It was concluded that the reduction of $\mathrm{Cr}$ (VI) was performed primarily by the Meiothermus utilising multicarbon nutrients released by the Methylosinus growing on methane [20]. This is consistent with observations that pure cultures of the well characterised alphaproteobacterial methanotroph Ms. trichosporium OB3b did not reduce Cr (VI) [41], while a mixed culture of Ms. trichosporium OB3b and a Cr (VI)-reducing strain of Escherichia coli was able to reduce $\mathrm{Cr}$ (VI) using methane as the only externally supplied carbon source (A. Al Hasin, T.J.
Smith and P.H.E. Gardiner, unpublished observations). Collectively, these data indicate that methanotrophs, whether in pure culture or mixed microbial communities, have the capacity to bioremediate $\mathrm{Cr}$ (VI) contamination over a wide range of concentrations using cheaply available methane as the feedstock.

\section{Interaction of methanothrophs with selenium}

Selenium is an essential micronutrient across all domains of life (including prokaryotes and humans), principally because of its role in selenocysteine in certain enzymes such as glycine reductase, formate dehydrogenase, glutathione peroxidase, iodothyronine deiodinase and thioredoxin reductase. Selenium is also a substantial environmental problem, where the toxic and watersoluble oxyanions selenite $\left(\mathrm{SeO}_{3}{ }^{2-}\right)$ and selenate $\left(\mathrm{SeO}_{4}{ }^{2-}\right)$ may be present from natural and anthropogenic sources and are a risk to humans, animals and other forms of life [138] (see Table 2 for case study on problems of selenium associated with the mining industry and beyond). Some bacteria are able to respire using selenate $\left(\mathrm{SeO}_{4}{ }^{2-}\right)$ as their terminal electron acceptor, while others are able to reduce selenium species to elemental selenium and perform methylation reactions $[40,139]$. The primary methylated forms of selenium produced by microorganisms are dimethyl selenide $\left(\mathrm{CH}_{3}-\mathrm{Se}-\mathrm{CH}_{3}\right)$ and dimethyl diselenide $\left(\mathrm{CH}_{3}-\mathrm{Se}-\mathrm{Se}-\mathrm{CH}_{3}\right)$, although others including dimethyl selenone $\left[\left(\mathrm{CH}_{3}\right)_{2} \mathrm{SeO}_{2}\right]$, dimethyl triselenide $\left(\mathrm{CH}_{3}\right.$-Se-Se-Se- $\left.\mathrm{CH}_{3}\right)$, methyl selenol $\left(\mathrm{CH}_{3}-\mathrm{Se}-\mathrm{H}\right)$ and mixed selenium/sulphur-methylated species such as dimethyl selenyl sulphide $\left(\mathrm{CH}_{3}-\mathrm{Se}-\mathrm{S}-\mathrm{CH}_{3}\right)$ and dimethyl selenyl disulphide $\left(\mathrm{CH}_{3}\right.$-Se-S-S- $\left.\mathrm{CH}_{3}\right)$ have also been observed $[40,49]$. Elemental selenium is insoluble and so is generally considered the most benign form of the element with lowest bioavailability. When ingested by mice, Se as nanoparticulate $\mathrm{Se}(0)$ had 7 -fold lower $\mathrm{LD}_{50}$ compared with Se as selenite [140]. In contrast, ingestion of $\mathrm{Se}(0)$ nanoparticles by fish has about 5 -fold lower $\mathrm{LD}_{50}$ compared with selenite. A study using the estuarine invertebrate Potamocorbula amurensis suggested that $\mathrm{Se}(0)$-rich particles produced by environmental consortia were more bioavailable than nanoparticulate $\mathrm{Se}(0)$ produced chemically or by pure bacterial cultures [141]. The diversity of selenium nanoparticles that can be produced by microorganisms may find applications in electronics and other industries [142-144].

Pure cultures of the Mc. capsulatus (Bath) or Ms. trichosporium OB3b do not detectably transform selenate, although both are able to remove selenite. The principal product is elemental selenium in the form of extracellular nanoparticles (Fig. 3a), as well as a small proportion that is converted to methylated Se species. The removal of selenite occurs more rapidly in Mc. capsulatus (Bath) compared with Ms. trichosporium OB3b (2-fold 
difference in rate observed in comparable tests in the laboratory), at the respective optimum temperatures (45 and $30^{\circ} \mathrm{C}$ ) of the two strains. Cultures of Mc. capsulatus (Bath) completely removed selenite from a starting concentration of $40 \mathrm{mg} \mathrm{L}^{-1}$ within $50 \mathrm{~h}$, with $75 \%$ conversion to elemental Se and the production of detectable methylated species (Fig. 3a [49];).

While it is not clear whether all volatile selenium species are produced via elemental Se reduction, $M c$. capsulatus (Bath) and Ms. trichosporium OB3b are each able to transform selenium nanoparticles into methylated species. Various mixtures of Se volatiles were detected, depending on the methanotroph strain used and the type of Se supplied (selenite, biogenic selenium nanoparticles produced by the methanotroph, or chemically produced selenium). Mc. capsulatus supplied with selenite produced the largest number of detectable $\mathrm{Se}$ volatiles: dimethyl selenide $\left(\mathrm{CH}_{3}-\mathrm{Se}-\mathrm{CH}_{3}\right)$, dimethyl diselenide $\left(\mathrm{CH}_{3}-\mathrm{Se}-\mathrm{Se}-\mathrm{CH}_{3}\right)$, dimethyl selenyl sulphide $\left(\mathrm{CH}_{3}\right.$-Se-S- $\left.\mathrm{CH}_{3}\right)$, methyl selenol $\left(\mathrm{CH}_{3}-\mathrm{Se}-\mathrm{H}\right)$ and methyl selenoacetate $\left(\mathrm{CH}_{3}-\mathrm{Se}-\mathrm{CH}_{2}-\mathrm{COOH}[49] ;\right)$.

A study by Lai and colleagues indicated that methanedriven conversion of selenate to elemental Se is possible [142]. A mixed community of microorganisms operating under anoxic conditions was able to perform methanedependent reduction of selenate to elemental selenium. This consortium contained a substantial population of genera associated with aerobic methane oxidation, particularly Methylomonas. A more recent study of a methane-driven selenate-reducing community in a membrane biofilm reactor, in which the predominant methanotrophs were Methylocystis, showed that the rate of selenate reduction peaked at an intermediate rate of oxygen supply. These results are consistent with a role of methane monooxygenase in the methanotrophs in oxygen-dependent conversion of methane to methanol as the principal carbon and energy source of the community. Cross-feeding from methanotrophs to non-methanotophs then enables reduction of selenate, via a reaction that is suppressed in the presence of excess oxygen. Consistent with this explanation, as the oxygen delivery rate was decreased to the intermediate level at which the rate of methane-driven selenate reduction was maximised, expression of pMMO genes (pmoA) decreased only 5.4-fold. At the same time, expression of nitrate reductase genes (narG, which may be involved in selenate reduction in non-methanotrophs including Variovorax and Arthrobacter) increased 50-fold [145].

The reduction and methylation of Se species by methanotrophs or consortia offer the possibility for methane-driven remediation and concentration of $\mathrm{Se}$ species, as well as producing $\mathrm{Se}$ as nanoparticles with novel properties that may be useful in electronics and other technologies, and for other uses such as addition as a micronutrient to selenium-poor foodstuffs.

The reduction of selenite to elemental selenium has been attributed to a range of reductase enzymes and also to non-enzymatic reactions of selenite with thiolcontaining molecules such as glutathione [40]. In Mc. capsulatus (Bath), analysis of the low molecular weight selenium-containing compounds during transformation of selenite and $\mathrm{Se}(0)$ suggested an extracellular mechanism of selenite reduction with methyl selenol as an intermediate [146]. Glutathione reductase, which has been implicated in the reduction of selenite in microorganisms including Pseudomonas stutzeri [147], appears to be absent from the genome of Mc. capsulatus (Bath), though is distributed among alpha- and gammaproteobacterial methanotroph genomes (Fig. 3b), being present in at least 49 out of 66 such genomes including that of Ms. trichosporium OB3b, the alphaproteobacterial methanotroph known to reduce selenite to Se (0).

\section{Mercury detoxification by methanotrophs}

Mercury (II) or $\mathrm{Hg}$ (II), a priority pollutant is released into environment to the tune of 4500-7500 tonnes per year. Around 55\% ( 1500 tonnes per annum) of global industrial mercury emissions arise from China, India and the USA [28]. Coal-fired industries, especially power generation, have been identified as the major source of mercury pollution alongside gold mining industries (Fig. 4; see Table 3 for case study on the extent of $\mathrm{Hg}$ pollution from artisanal/small scale gold mining from Guyana) $[29,148]$. In the environment, elemental mercury $(\mathrm{Hg}(0))$ is oxidised to inorganic $\mathrm{Hg}$ (II), which can then react with various organic compounds in water and soil sediment by biotic reactions facilitated by bacteria, and abiotic reactions mediated by sunlight photolysis, resulting in conversion into organic mercury such as methylmercury [148]. Methyl mercury $\left(\mathrm{CH}_{3} \mathrm{Hg}^{+}\right)$, which is a more toxic form than $\mathrm{Hg}$ (II) or $\mathrm{Hg}(0)$, can easily be absorbed by organisms from the lower levels of the food chain and accumulated in higher trophic organisms e.g. through fishes to humans. Methyl mercury can affect the human body negatively, especially the nervous system and is particularly dangerous for pregnant women as the foetus can be affected by mercury passing through the placenta. Damage done to the brains of babies leads to symptoms such as deafness, blindness, microcephally, cerebral palsy and problems with swallowing [28]. Methanotrophs are able to reduce mercury and detoxify methyl mercury $[149,150]$. Recently Shi and colleagues [150] reported the presence of all genes required for the reduction of $\mathrm{Hg}$ (II) in a metagenome-assembled genome of the alphaproteobacterial methanotroph Methylocystis. Our analysis of representative genomes (Fig. 3b) detected merA genes in most of the gammaproteobacterial 
methanotrophs (13 out of 44), all of verrucomicrobial methanotrophs (6 out of 6 ) and in a very few alphaproteobacterial methanotrophs (4 out of 22). We also detected two copies of the merA gene in few methanotrophs such as Methylacidiphilum fumariolicum, Methylacidiphilum kamchatkense and Methylocystis sp. MitZ-2018. However, in other methanotroph genomes, we detected copies of merA homologues i.e. dihydrolipoamide dehydrogenase (DLD) and/or NADPH-glutathione reductase (gor $A$ ) genes. GorA, DLD and MerA belong to the family of flavin-dependent disulphide oxidoreductases that are mainly involved in redox reactions [151]. It has been reported that $\mathrm{Hg}$ (II) can bind strongly with sulfohydryl groups of proteins [152-155]. Previously characterised GorA and DLD enzymes are inhibited by $\mathrm{Hg}$ (II) upon binding at their sulfohydral binding sites, while MerA is catalytically active in the presence of $\mathrm{Hg}$ (II) [156]. This difference in the inhibitory effects of $\mathrm{Hg}$ (II) could be mainly due to the structural and redox cycling differences between the GorA or DLD and MerA [156, 157]. The possible role of DLD and GorA homologous proteins on $\mathrm{Hg}$ (II) or $\mathrm{CH}_{3} \mathrm{Hg}^{+}$reduction and or detoxification in methanotrophs needs to be investigated.

It has been reported that there are two different mechanisms through which the specific enzymes are deactivated by binding of $\mathrm{Hg}$ (II). First mechanism: $\mathrm{Hg}$ (II) usually binds with proteins containing thiols (e.g. cysteine) and thioethers (e.g. methionine) causing protein unfolding, aggregation and precipitations [158]. Specifically, the $\mathrm{N}$-termal cysteine residues are critical for $\mathrm{Hg}(\mathrm{II})$ binding and transport [156]. Second mechanism: In the absence of cysteine side chains, histidine binds $\mathrm{Hg}$ (II) at the constant of $\log K_{\mathrm{f}}-7.4$ [159]. Moreover, Stratton and colleagues [158] reported that the S-ligands offer higher binding constants with $\mathrm{Hg}$ (II) (i.e. $\log K_{\mathrm{f}}-14.4-52.7$ ) in comparison to $\mathrm{N}$-ligands (i.e. $\log K_{\mathrm{f}} 3.5-8.8$ ).

Methanobactin can bind $\mathrm{Hg}$ (II) similar to $\mathrm{Cu}$ (II) or $\mathrm{Cu}$ (I) (binding with both oxazolone rings at the rate $>2000$ $\mathrm{s}^{-1}$ ) [52]. As discussed above, methanobactins contain cysthiols groups that readily bind $\mathrm{Hg}$ (II). However, the binding ratios differ for methanobactins from Ms. trichospoium OB3b and Methylocystis sp. strain SB2, which might be linked to the presence of different heterocyclic rings and associated enithiols [119]. It has been reported that the binding of $\mathrm{Hg}$ :methanobactin ratio were different for Ms. trichosporium OB3b-methanobactin (i.e. 0.1) and Methylocystis sp. strain SB2-methanobactin (i.e. 0.5-6), while the $\mathrm{Hg}$ replaced the $\mathrm{Cu}$ from Methylocystis sp. strain SB2-methanobactin when added together. Moreover, the binding ratios of methanobactin with different $\mathrm{Hg}$ species (e.g. $\mathrm{Hg}(\mathrm{II}), \mathrm{CH}_{3} \mathrm{Hg}^{+}$or $\mathrm{Hg}(\mathrm{CN})_{2}$ ) are significantly different for the two methanobactins due to their structural disparity.
Baral and colleagues [119] observed that $\mathrm{Hg}$ (II) is reduced (presumably to $\mathrm{Hg}(0)$ as inferred from the appearance of a grey colour) by methanobactin from $M s$. trichosporium OB3b, but not from Methylocystis sp. strain SB2. Similarly, $\mathrm{Hg}$ (0) produced from $\mathrm{Hg}$ (II) by Ms. trichosporium OB3b producing methanobactin is not volatile but associated with the biomass at a protein: mercury mass ratio of approximately 2:1 [50]. Methanobactin has been shown to bind with $\mathrm{CH}_{3} \mathrm{Hg}^{+}$, particularly with oxazolone rings and not with other heterocyclic ring [119]. Methanotrophs lacking the ability to produce methanobactin are able to take up $\mathrm{CH}_{3} \mathrm{Hg}^{+}[42,149]$, but their accumulation capacity is comparatively lower. It is hypothesised that the methanobactin facilitated uptake of $\mathrm{CH}_{3} \mathrm{Hg}^{+}$(e.g. $100 \mathrm{nM}$ to up to $500 \mu \mathrm{M})$ can result in conversion into inorganic $\mathrm{Hg}$ by an non-conventional 'oxidative demethylation' (i.e. not through the conventional organomercurial lyase encoded by merB) $[52,160]$. In contrast to the $\mathrm{CH}_{3} \mathrm{Hg}^{+}$ degradation system of methanotrophs, MerB enzymes usually show very poor affinity for $\mathrm{CH}_{3} \mathrm{Hg}^{+}(\mathrm{Km}$ around $500 \mu \mathrm{M})$ and are expressed only under certain environmental conditions such as concentrations of $\mathrm{Hg}>1 \mu \mathrm{M}$ and $\mathrm{pH}>7.0$ (optimum $\mathrm{pH} \sim 10.2$ ) [42]. Not all methanotrophs degrade $\mathrm{CH}_{3} \mathrm{Hg}^{+}$; e.g. Ms. trichosporium OB3b can degrade $\mathrm{CH}_{3} \mathrm{Hg}^{+}$, while $M$. album BG8 cannot. It has been speculated that the $\mathrm{CH}_{3} \mathrm{Hg}^{+}$initially binds with methanobactin and is internalised for $\mathrm{MeDH}$ to cleave the $\mathrm{C}-\mathrm{Hg}^{+}$bonds in Ms. trichosporium OB3b, as shown by the inhibition of demethylation of $\mathrm{CH}_{3} \mathrm{Hg}^{+}$when methanol is added. Overall, mechanistic understanding of demethylation characteristics in methanotrophs will allow researchers to develop remediation strategies for contaminated environments. While there is no evidence of $\mathrm{Hg}$ (II) methylation by methanotrophs, the role of methanobactin on $\mathrm{Hg}$ (II) methylation in the presence of Geobacter sulfurreducens PCA and Desulfovibrio desulfuricans ND132 was recently reported [120]. Since there are no studies reporting the specific binding proteins from methanotrophs other than methanobactin regulating $\mathrm{Hg}$ (II) and $\mathrm{CH}_{3} \mathrm{Hg}^{+}$toxicity, there is a need to characterise methanotroph cell surface proteins with sulfohydral groups to understand their possible role in $\mathrm{Hg}$ (II) and $\mathrm{CH}_{3} \mathrm{Hg}^{+}$binding and transport [155].

\section{Factors affecting metal transformation by methanotrophs} A number of abiotic factors can affect the passive or active metal uptake systems and transformation by methanotrophs, among which $\mathrm{pH}$, temperature, available oxygen concentrations, carbon source (e.g. $\left.\mathrm{CH}_{4}\right)$ and other metal(loid)s coordination play a critical role. Metal affinity of methanobactin is influenced by pH (Fig. 5 [119];) along with metal to methanotroph biomass (and methanobactin) ratio. The binding rate and affinity can 


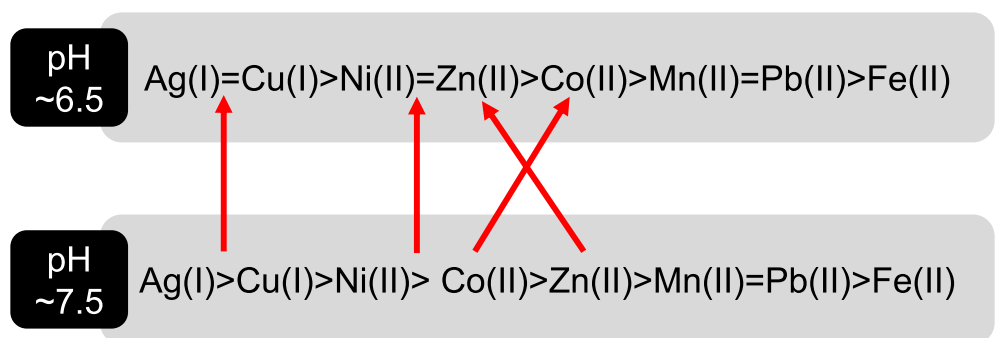

Fig. 5 Order of metal affinity for methanobactin under different $\mathrm{pH}$ conditions (red arrow indicate the order of change in metal afficinity with respect to $\mathrm{pH}$ change)

alter with the molar ratio of metal to methanobactin (i.e. $\mathrm{Cu}$ and methanobactin). If the ratio is 0.5 or above, methanobactin binds as a monomer and at lower ratios as tetramer or oligomer. In the presence of other metals, $\mathrm{Cu}$ will be the preferred metal ion that will be readily taken up by the methanotrophs, while least preferred is iron. In presence of $\mathrm{Ag}$ (I) or $\mathrm{Au}$ (II), the copper uptake will be limited. Our understanding of the physiology of methanotrophs, particularly the regulation of genes (e.g. TonB, mbn $A B C M$, ars $R B C$, mer $A B C D$, etc.) for metal uptake and/or transformations in relation to concentrations of $\mathrm{Cu}$ and other metals is limited. Uptake of $\mathrm{Zn}$ can be affected by $\mathrm{Hg}$ (II) or Cd, which are thiophilic in nature and bind to the cysteine in methanobactin. Temperature influences the solubility of methane in solution and thereby influences methanotrophic growth, which in turn may significantly influence metal ion uptake. However, there is no detailed understanding on how metal affinity for methanobactin and other methanotroph metal uptake systems varies at different temperatures. While methanotrophs with no capacity to make methanobactin can also uptake and accumulate metals, studies on these methanotrophs are also very limited. Pure cultures and mixed methanotrophs cultures with or without heterotrophs (that mimic natural conditions) may also behave differently in metal uptake and transformations and future research is required to understand metal transformations in near in situ conditions. Lai and colleagues [161] found that the available nitrate had significant impact on bromate reduction, while they also correlated it with polyhydroxyalkanoate (PHA) accumulation capacity. However, not all the strains can make PHA as storage material.

A range of biotic interactions (e.g. methanotroph-heterotroph interactions; Fig. 6) can regulate methanotroph distribution, activity, metal uptake and transformation $[71,162,163]$. Both synergistic and antagonistic biotic interactions are known to impact methanotroph

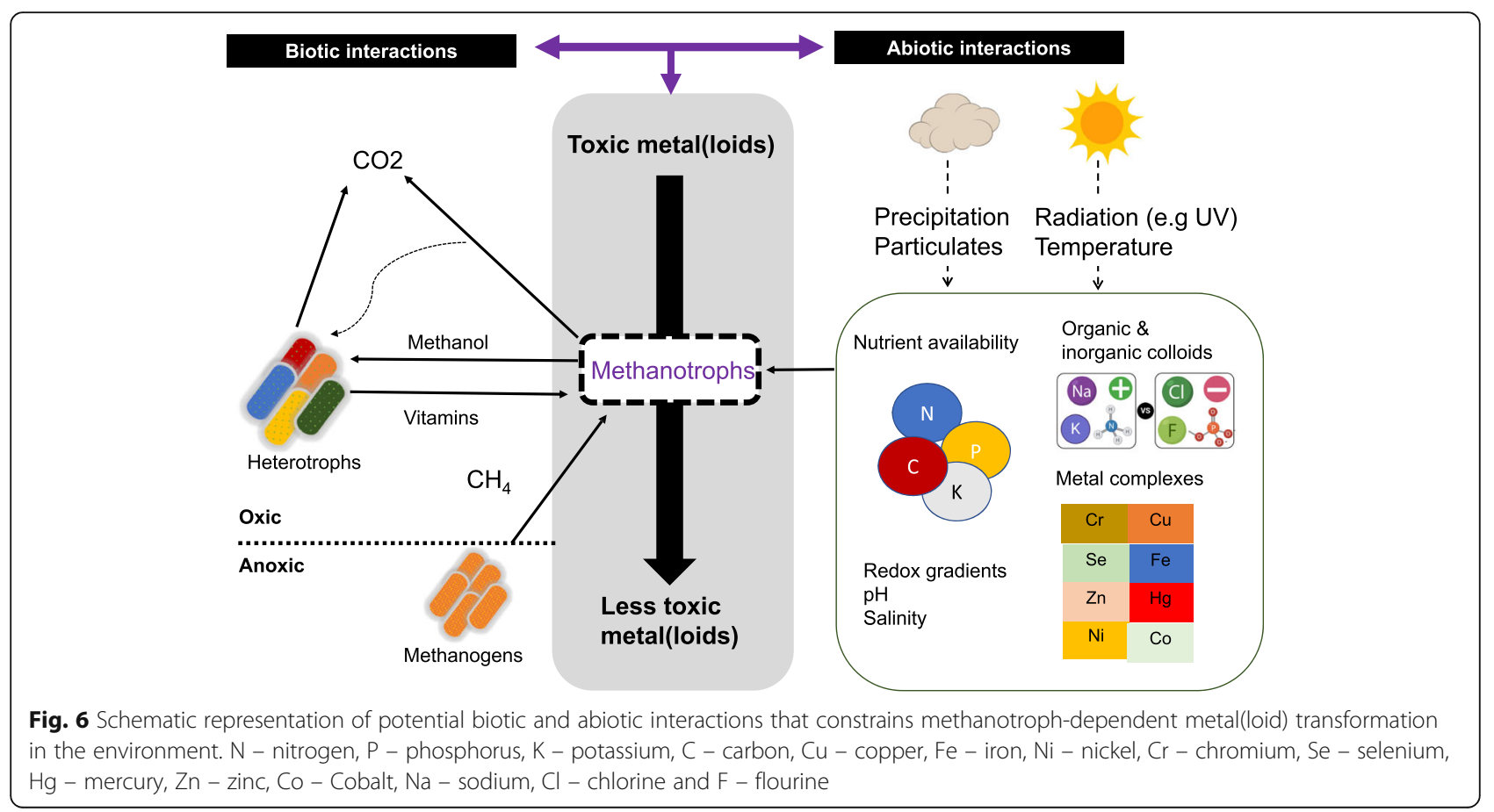


functional diversity and have been extensively reviewed in [162]. It has been well-established that exchange of metabolites between methanotrophs and heterotrophs improve methanotroph growth and activity [163, 164]. Methanotroph-heterotroph interactions are also constrainted by various abiotic factors. For instance, the ratio of $\mathrm{CH}_{4}$ to $\mathrm{O}_{2}$ altered the methanotroph-heterotroph community structure in the enrichment. In particular, PHB accumulating alphaproteobacterial methanotrophs dominanted with increasing $\mathrm{CH}_{4}$ content $[165,166]$. Moreover, differences in $\mathrm{Cu}$ to $\mathrm{Fe}$ ratio were also found to impact community composition [167]. Our understanding on the role of biotic interactions on metal transformation by methanotrophs is currently limited. Given the potential role of methanotrophs in bioremediation strategies, there is an immediate need to explore how community level biotic interactions impact metal transformations and uptake.

\section{Conclusions and future considerations}

Manufacturing and resources industries are key drivers for economic growth, yet this comes at a huge environmental cost affecting not only ecosystem services but also the livelihood of local communities. Aerobic methanotrophs are metabolically versatile and are able to detoxify toxic heavy metals such as chromium and mercury while growing on a cheap feedstock i.e. methane. In order to fully exploit these traits for mitigation of polluted sites, future research is required to better understand (i) physiological and genetic basis of $\mathrm{Cr}(\mathrm{VI})$ reduction and demethylation of mercury, (ii) mechanism of $\mathrm{Cu}$ reduction by methanobactin, (iii) role of porins in passive uptake of metals in methanotrophs, and (iv) role of molybdenum and tungsten in formate dehydrogenase activity. More importantly, our knowledge of metal transformations by methanotrophs is based to a large extent on laboratory strains. Further research is required to understand metal uptake/transformation mechanisms in the environment, particularly in polluted sites with elevated and/or multiple metal concentrations.

\section{Acknowledgements}

The authors thank Mr Khaleel Mohammed (Erode Tannery Limited) for useful discussions and two anonymous reviewers for their insightful comments.

\section{Authors' contributions}

OPK and DK conceived the idea and and all authors contributed to the final draft. The author(s) read and approved the final manuscript.

\section{Funding}

We acknowledge the funding from the Department for Economy (DfE) - Global Challenges Research (GCRF) grant to DK and GCRF-Global Impact Accelerator Award to DK and PNW, BBSRC (BB/C00399X/1 and BB/ F01449X/1), UK Science and Technology Facilities Council and European Synchotron Radiation Facility for TJS.

\section{Availability of data and materials}

The datasets (genome sequences) analysed during the current study are available through NCBI genome assembly repository (www.ncbi.nlm.nih.gov)

\section{Declarations}

Ethics approval and consent to participate

Not applicable

\section{Consent for publication}

Not applicable

\section{Competing interests}

The authors declare no competing interests.

\section{Author details}

${ }^{1}$ School of Biological Sciences \& Institute for Global Food Security, Queen's University Belfast, 19 Chlorine Gardens, Belfast, UK. ${ }^{2}$ Civil and Environmental Engineering, University of Michigan, Ann Arbor, MI, USA. ${ }^{3}$ Department of Engineering Technology, College of Technology, University of Houston, Houston, TX, USA. ${ }^{4}$ Biomolecular Sciences Research Centre, Sheffield Hallam University, Sheffield, UK. ${ }^{5}$ Department of Environmental Sciences, Tamil Nadu Agricultural University, Coimbatore, India. ${ }^{6}$ Department of Chemistry, University of Guyana, Georgetown, Guyana. ${ }^{7}$ Faculty of Science, SRM University, Chennai, India.

Received: 21 January 2021 Accepted: 9 June 2021

Published online: 06 July 2021

\section{References}

1. Kotrba P, Najmanova J, Macek T, Ruml T, Mackova M. Genetically modified plants in phytoremediation of heavy metal and metalloid soil and sediment pollution. Biotechnol Adv. 2009;27(6):799-810. https://doi.org/10.1016/j. biotechadv.2009.06.003.

2. Nabulo G, Young SD, Black CR. Assessing risk to human health from tropical leafy vegetables grown on contaminated urban soils. Sci Total Environ. 2010;408(22):5338-51. https://doi.org/10.1016/.scitotenv.2010.06.034.

3. Aryal M, Liakopoulou-Kyriakides M. Bioremoval of heavy metals by bacterial biomass. Environ Monit Assess. 2015;187(1):4173. https://doi.org/10.1007/s1 0661-014-4173-z.

4. Nagajyoti PC, Lee KD, Sreekanth TVM. Heavy metals, occurrence and toxicity for plants: a review. Environ Chem Lett. 2010;8(3):199-216. https://doi.org/1 0.1007/s10311-010-0297-8.

5. Chistoserdova L, Kalyuzhnaya MG. Current trends in methylotrophy. Trends Microbiol. 2018;26(8):703-14. https://doi.org/10.1016/j.tim.2018.01.011.

6. Barbosa F Jr. Toxicology of metals and metalloids: promising issues for future studies in environmental health and toxicology. J Toxicol Environ Health A. 2017;80(3):137-44. https://doi.org/10.1080/15287394.2016.1259475.

7. Dalcorso G, Fasani E, Furini A. Recent advances in the analysis of metal hyperaccumulation and hypertolerance in plants using proteomics. Front Plant Sci. 2013:4:280

8. Jaishankar M, Tseten T, Anbalagan N, Mathew BB, Beeregowda KN. Toxicity, mechanism and health effects of some heavy metals. Interdiscip Toxicol. 2014;7(2):60-72. https://doi.org/10.2478/intox-2014-0009.

9. Jan AT, Azam M, Siddiqui K, Ali A, Choi I, Haq QMR. Heavy metals and human health: mechanistic insight into toxicity and counter defense system of antioxidants. Int J Mol Sci. 2015;16(12):29592-630. https://doi.org/10.3390/ ijms161226183.

10. Meena RAA, Sathishkumar P, Ameen F, Yusoff ARM, Gu FL. Heavy metal pollution in immobile and mobile components of lentic ecosystems-a review. Env Sci Pollut R. 2018;25(5):4134-48. https://doi.org/10.1007/s11356017-0966-2.

11. Wu X, Cobbina SJ, Mao G, Xu H, Zhang Z, Yang L. A review of toxicity and mechanisms of individual and mixtures of heavy metals in the environment. Environ Sci Pollut R. 2016;23(9):8244-59. https://doi.org/10.1007/s11356-0166333-x.

12. Ramasamy K, Naidu R. Status of tanning industries in India. In: Towards better management of soils contaminated with tannery waste. Canberra: Australian Centre for International Agricultural Research; 1998. p. 13-21. 
13. World Health Organisation \& International Programme on Chemical Safety Guidelines for drinking-water quality, vol. 2. Health Criteria and supporting information. 2nd ed. 1996.

14. Sunitha R, Gayathri P, Bharani A, Mahimairajah SJ. Chromium contamination in soil and groundwater due to tannery waste disposals at Vellore district of Tamil Nadu. Int J Environ Sci. 2015:6:114-24.

15. Naidu R, Kookana RS, Cox J, Mowat D, Smith LH. Fate and chromium at tannery waste contaminated sites at Mount Barker. In: Towards better management of soils contaminated with tannery waste. In: ACIAR (Australian Centre for International Agricultural Research) proceedings. Canberra; 2000. p. 57-70

16. Avudainayagam S, Naidu R, Kookana R, Angus A, Smith LH. Effect of electrolyte composition on chromium desorption in soil contaminated by tannery waste. Aust J Soil Res. 2001;39(5):1077-89. https://doi.org/10.1071/ SR00085.

17. Kamaludeen SPB, Banu P, Megharaj M, Juhasz A, Sethunathan N, Naidu R. Chromium-Microorganism interactions in soil: implications to remediation. Rev Environ Contam T. 2003;178:93-164.

18. Sethunathan N, Megharaj M, Smith L, Kamaludeen SPB, Avudainayagam S, Naidu R. Microbial role in the failure of natural attenuation of $\mathrm{Cr}(\mathrm{VI})$ in longterm tannery waste contaminated soil. Agric Ecosyst Environ. 2005;105(4): 657-61. https://doi.org/10.1016/j.agee.2004.08.008.

19. Hausladen DM, Fendorf S. Hexavalent chromium generation within naturally structured soils and sediments. Environ Sci Technol. 2017;51(4):2058-67. https://doi.org/10.1021/acs.est.6b04039.

20. Lai C, Wen L, Shi L, Zhao K, Wang Y, Yang X, et al. Bioreduction of chromate in a methane-based membrane biofilm reactor. Environ Sci Technol. 2016; 50(18):10179-86. https://doi.org/10.1021/acs.est.6b02807.

21. WHO: Trace elements in human nutrition and health. 1996.

22. Ohlendorf HM, Kilness AW, Simmons JL, Stroud RK, Hoffman DJ, Moore JF. Selenium toxicosis in wild aquatic birds. J Toxicol Environ Health. 1988;24(1): 67-92. https://doi.org/10.1080/15287398809531141.

23. Etteieb S, Magdouli S, Zolfaghari M, Brar S. Monitoring and analysis of selenium as an emerging contaminant in mining industry: a critical review. Sci Total Environ. 2020;698:134339. https://doi.org/10.1016/j.scitotenv.201 9.134339 .

24. Izquierdo M, Querol X. Leaching behaviour of elements from coal combustion fly ash: an overview. Int J Coal Geol. 2012;94:54-66. https://doi. org/10.1016/j.coal.2011.10.006.

25. George A, Shen B, Kang D, Yang J, Luo J. Emission control strategies of hazardous trace elements from coal-fired power plants in China. Environ Sci (China). 2020;93:66-90. https://doi.org/10.1016/j.jes.2020.02. 025.

26. Srigboh RK, Basu N, Stephens J, Asampong E, Perkins M, Neitzel RL, et al. Multiple elemental exposures amongst workers at the Agbogbloshie electronic waste (e-waste) site in Ghana. Chemosphere. 2016;164:68-74. https://doi.org/10.1016/j.chemosphere.2016.08.089.

27. Skalickova S, Milosavljevic V, Cihalova K, Horky P, Richtera L, Adam V. Selenium nanoparticles as a nutritional supplement. Nutrition. 2017;33:8390. https://doi.org/10.1016/j.nut.2016.05.001.

28. United Nations Environmental Programme. Global mercury assessment sources, emissions, releases and environmental transport. Geneva: UNEP; 2013. https://wedocs.unep.org/20.500.11822/7984.

29. Telmer KH, Veiga MM, Mason R, Pirrone N, Boston MA. World emissions of mercury from artisanal and small scale gold mining. In: Pirrone N, Mason R, editors. Mercury fate and transport in the global atmosphere. Boston: Springer; 2009.

30. Bank of Guyana. Annual Report. Bank of Guyana Georgetown; 2018.

31. Pasha S, Wenner MD, Clarke D. Toward the greening of the gold mining sector of Guyana: transition issues and challenges. Georgetown: Country Department Caribbean Group; 2017

32. WWF-Guinanas: Gold miner's knowledge, attitudes and practice with regards to mercury: a study in three small-scale gold mining regions in Suriname. 2014

33. Romero R, Ohashi C, Williams P, Hourty T, Bynore P, Insanally O. Guyana Minamata initial assessment report; 2016.

34. Legg ED, Ouboter PE, Wright MAP. Small-scale gold mining related mercury contamination in the Guianas: a review. Paramaribo: World Wildlife Fund; 2015.

35. Howard J, Trotz MA, Thomas K, Omisca E, Chiu HT, Halfhide T, et al. Total mercury loadings in sediment from gold mining and conservation areas in
Guyana. Environ Monit Assess. 2011;179(1-4):555-73. https://doi.org/10.1007/ s10661-010-1762-3.

36. Singh H, Bernard C, Rampersaud P, Laing T, Balraj D, Priester M, et al. Guyana's extractive industry sector (EIS): a synopsis of issues and recommendations for the mining sector as a sustainable element of Guyana's low carbon development strategy (LCDS): Cl-Guyana. Georgetown: Projekt-Consult GmbH and WWF Guianas; 2018.

37. Environmental Protection Agency. State of the Environment Report Georgetown Guyana 2016

38. Bolan N, Kunhikrishnan A, Thangarajan R, Kumpiene J, Park J, Makino T, et al. Remediation of heavy metal(loid)s contaminated soils--to mobilize or to immobilize? J Hazard Mater. 2014;266:141-66. https://doi.org/10.1016/j.jha zmat.2013.12.018.

39. Ma Y, Oliverira R, Freitas $H$, Zhang C. Biochemical and molecular mechanisms of plant-microbe-metal interactions: relevance for phytoremediation. Front Plant Sci. 2016;7:918.

40. Eswayah AS, Smith TJ, Gardiner PHE. Microbial transformations of selenium species of relevance to bioremediation. Appl Environ Microbiol. 2016;82(16): 4848-59. https://doi.org/10.1128/AEM.00877-16.

41. Hasin A, Gurman SJ, Murphy LM, Perry A, Smith TJ, Gardiner PHE. Remediation of chromium (VI) by a methane-oxidising bacterium. Environ Sci Technol. 2010;44(1):400-5. https://doi.org/10.1021/es901723c.

42. Lu X, Gu W, Zhao L. Farhan UI Haque M, DiSpirito AA, Semrau JD, Gu B: Methylmercury uptake and degradation by methanotrophs. Sci Adv. 2017; 3(5):e1700041. https://doi.org/10.1126/sciadv.1700041.

43. Borch T, Kretzschmar R, Kappler A, Cappellen PV, Ginder-Vogel M, Voegelin A, et al. Biogeochemical redox processes and their impact on contaminant dynamics. Environ Sci Technol. 2010;44(1):15-23. https://doi.org/10.1021/ es9026248.

44. Gadd GM. Metals, minerals and microbes: geomicrobiology and bioremediation. Microbiology (Reading). 2010;156(Pt 3):609-43. https://doi. org/10.1099/mic.0.037143-0.

45. Reeder RJ, Schoonen MAA, Lanzirotti A. Metal speciation and its role in bioaccessibility and bioavailability. Rev Mineral Geochem. 2006;64(1):59-113. https://doi.org/10.2138/rmg.2006.64.3.

46. Abbas G, Murtaza B, Bibi I, Shahid M, Niazi NK, Khan Ml, et al. Arsenic uptake, toxicity, detoxification, and speciation in plants: physiological, biochemical, and molecular aspects. Int J Environ Res Public Health. 2018;15(1):59. https://doi.org/10.3390/ijerph15010059.

47. Wang D, Liang D, Wang S, Hu B, Wei W. Individual and joint toxicity effects of $\mathrm{Cu}, \mathrm{Cr}(\mathrm{III})$, and $\mathrm{Cr}(\mathrm{VI})$ on pakchoi: a comparison between solution and soil cultures. Biol Trace Elem Res. 2012;146(1):116-23. https://doi.org/10.1007/s12 011-011-9219-2

48. Obrist D, Kirk JL, Zhang L, Sunderland EM, Jiskra M, Selin NE. A review of global environmental mercury processes in response to human and natural perturbations: Changes of emissions, climate, and land use. Ambio. 2018; 47(2):116-40. https://doi.org/10.1007/s13280-017-1004-9.

49. Eswayah AS, Smith TJ, Scheinost AC, Hondow N, Gardiner PHE. Microbial transformations of selenite by methane-oxidizing bacteria. Appl Microbiol Biotechnol. 2017;101(17):6713-24. https://doi.org/10.1007/ s00253-017-8380-8.

50. Vorobev A, Jagadevan S, Baral BS, Dispirito AA, Freemeier BC, Bergman BH, et al. Detoxification of mercury by methanobactin from Methylosinus trichosporium OB3b. Appl Environ Microbiol. 2013;79(19):5918-26. https:// doi.org/10.1128/AEM.01673-13.

51. Kalyuzhnaya MG, Gomez OA, Murrell JC. The methane-oxidizing bacteria (methanotrophs). In Taxonomy, genomics and ecophysiology of hydrocarbon-degrading microbes. Edited by McGenity TJ. Cham: Springer Springer Nature; 2019. p. 1-34.

52. Semrau JD, DiSpirito AA, Gu W, Yoon S. Metals and methanotrophy. Appl Environ Microbiol. 2018:84(6):e02289-17.

53. Ettwig KF, Zhu B, Speth D, Keltjens JT, Jetten MSM, Kartal B. Archaea catalyze iron-dependent anaerobic oxidation of methane. P Natl Acad Sci USA. 2016;113(45):12792-6. https://doi.org/10.1073/pnas.1609534113.

54. Vigneron A, Alsop EB, Cruaud P, Philibert G, King B, Baksmaty L, et al. Contrasting pathways for anaerobic methane oxidation in gulf of Mexico cold seep sediments. mSystems. 2019;4(1):e00091-18.

55. Versantvoort W, Guerrero-Cruz S, Speth DR, Frank J, Gambelli L, Cremers G, et al. Comparative genomics of Candidatus Methylomirabilis species and description of Ca. Methylomirabilis Lanthanidiphila. Front Microbiol. 2018:9: 1672. https://doi.org/10.3389/fmicb.2018.01672. 
56. Antony CP, Kumaresan D, Ferrando L, Boden R, Moussard H, Scavino AF, et al. Active methylotrophs in the sediments of Lonar Lake, a saline and alkaline ecosystem formed by meteor impact. ISME J. 2010;4(11):1470-80. https://doi.org/10.1038/ismej.2010.70.

57. Kumaresan D, Abell GCJ, Bodrossy L, Stralis-Pavese N, Murrell JC. Spatial and temporal diversity of methanotrophs in a landfill cover soil are differentially related to soil abiotic factors. Environ Microbiol Rep. 2009;1(5):398-407. https://doi.org/10.1111/j.1758-2229.2009.00059.x.

58. Kumaresan D, Stephenson J, Doxey AC, Bandukwala H, Brooks E, HillebrandVoiculescu A, et al. Aerobic proteobacterial methylotrophs in Movile Cave: genomic and metagenomic analyses. Microbiome. 2018;6(1):1. https://doi. org/10.1186/s40168-017-0383-2.

59. Sheng $R$, Chen A, Zhang M, Whiteley AS, Kumaresan D, Wei W. Transcriptional activities of methanogens and methanotrophs vary with methane emission flux in rice soils under chronic nutrient constraints of phosphorus and potassium. Biogeosciences. 2016;13(23):6507-18. https:// doi.org/10.5194/bg-13-6507-2016.

60. Trotsenko YA, Murrell JC. Metabolic aspects of aerobic obligate methanotrophy. Adv Appl Microbiol. 2008;63:183-229. https://doi.org/10.101 6/S0065-2164(07)00005-6.

61. Tavormina PL, Orphan VJ, Kalyuzhnaya MG, Jetten MSM, Klotz MG. A novel family of functional operons encoding methane/ammonia monooxygenaserelated proteins in gammaproteobacterial methanotrophs. Environ Microbiol Rep. 2011;3(1):91-100. https://doi.org/10.1111/j.1758-2229.2010. 00192.x.

62. Glass JB, Orphan VJ. Trace metal requirements for microbial enzymes involved in the production and consumption of methane and nitrous oxide. Front Microbiol. 2012;3:61.

63. Takeguchi M, Ohashi M, Okura I. Role of iron in particulate methane monooxygenase from Methylosinus trichosporium OB3b. Biometals. 1999; 12(2):123-9. https://doi.org/10.1023/A:1009257826998.

64. Ross MO, MacMillan F, Wang J, Nisthal A, Lawton TJ, Olafson BD, et al. Particulate methane monooxygenase contains only mononuclear copper centers. Science. 2019;364(6440):566-70. https://doi.org/10.1126/ science.aav2572.

65. Bordel S, Rodriguez Y, Hakobyan A, Rodriguez E, Lebrero R, Munoz R. Genome scale metabolic modeling reveals the metabolic potential of three type II methanotrophs of the genus Methylocystis. Metab Eng. 2019;54:1919. https://doi.org/10.1016/j.ymben.2019.04.001.

66. Hakobyan A, Liesack W. Unexpected metabolic versatility among type II methanotrophs in the Alphaproteobacteria. Biol Chem. 2020;401(12):146977. https://doi.org/10.1515/hsz-2020-0200.

67. Kalyuzhnaya MG, Puri AW, Lidstrom ME. Metabolic engineering in methanotrophic bacteria. Metab Eng. 2015;29:142-52. https://doi.org/10.101 6/j.ymben.2015.03.010

68. Murrell JC, Smith TJ. Biochemistry and Molecular biology of methane monooxygenase. In: Timmis KN, editor. Handbook of Hydrocarbon and Lipid Microbiology. Berlin, Heidelberg: Springer; 2010.

69. Semrau JD, DiSpirito AA, Yoon S. Methanotrophs and copper. FEMS Microbiol Rev. 2010;34(4):496-531. https://doi.org/10.1111/j.1574-6976.2010. 00212.x.

70. Sirajuddin S, Rosenzweig AC. Enzymatic oxidation of methane. Biochemistry. 2015;54(14):2283-94. https://doi.org/10.1021/acs.biochem.5b00198.

71. Chidambarampadmavathy K, Karthikeyan OP, Huerlimann R, Maes GE, Heimann K. Response of mixed methanotrophic consortia to different methane to oxygen ratios. Waste Manag. 2017;61:220-8. https://doi.org/10.1 016/j.wasman.2016.11.007.

72. DiSpirito AA, Semrau JD, Murrell JC, Gallagher WH, Dennison C, Vuilleumier S. Methanobactin and the link between copper and bacterial methane oxidation. Microbiol Mol Biol Rev. 2016;80(2):387-409. https://doi.org/10.112 8/MMBR.00058-15

73. Choi D-W, Kunz RC, Boyd ES, Semrau JD, Antholine WE, Han Jl, et al. The membrane-associated methane monooxygenase (pMMO) and pMMO$\mathrm{NADH}$ :quinone oxidoreductase complex from Methylococcus capsulatus Bath. J Bacteriol. 2003;185(19):5755-64. https://doi.org/10.1128/JB.185.19. 5755-5764.2003.

74. Dassama LMK, Kenney GE, Ro SY, Zielazinski EL, Rosenzweig AC. Methanobactin transport machinery. P Natl Acad Sci USA. 2016;113(46): 13027-32. https://doi.org/10.1073/pnas.1603578113.

75. Kalyuzhnaya MG, Yang S, Rozova ON, Smalley NE, Clubb J, Lamb A, et al. Highly efficient methane biocatalysis revealed in a methanotrophic bacterium. Nat Commun. 2013;4(1):2785. https://doi. org/10.1038/ncomms3785.

76. Osborne CD, Haritos VS. Horizontal gene transfer of three co-inherited methane monooxygenase systems gave rise to methanotrophy in the Proteobacteria. Mol Phylogenet Evol. 2018;129:171-81. https://doi.org/10.101 6/j.ympev.2018.08.010.

77. Vekeman B, Kerckhof F-M, Cremers G, de Vos P, Vandamme P, Boon N. Op den Camp HJM, Heylen K: New Methyloceanibacter diversity from North Sea sediments includes methanotroph containing solely the soluble methane monooxygenase. Environ Microbiol. 2016;18(12):4523-36. https:// doi.org/10.1111/1462-2920.13485

78. Chu F, Lidstrom ME. XoxF acts as the predominant methanol dehydrogenase in the type I methanotroph Methylomicrobium buryatense. J Bacteriol. 2016;198(8):1317-25. https://doi.org/10.1128/JB.00959-15.

79. Pol A, Barends TRM, Dietl A, Khadem AF, Eygensteyn J, Jetten MSM. Op den Camp HJM: Rare earth metals are essential for methanotrophic life in volcanic mudpots. Environ Microbiol. 2014;16(1):255-64. https://doi.org/1 $0.1111 / 1462-2920.12249$.

80. Wu ML, Wessels JCT, Pol A. Op den Camp HJM, Jetten MSM, van Niftrik L: XoxF-type methanol dehydrogenase from the anaerobic methanotroph "Candidatus Methylomirabilis oxyfera". Appl Environ Microbiol. 2015;81(4): 1442-51. https://doi.org/10.1128/AEM.03292-14.

81. Yu Z, Chistoserdova L. Communal metabolism of methane and the rare earth element switch. J Bacteriol. 2017;199(22):e00328-17. https://doi.org/ $0.1128 / J B .00328-17$

82. Anthony $C$, Williams $P$. The structure and mechanism of methanol dehydrogenase. Biochim Biophys Acta. 2003;1647(1-2):18-23. https:/doi. org/10.1016/\$1570-9639(03)00042-6.

83. Kalyuzhnaya MG, Hristova KR, Lidstrom ME, Chistoserdova L. Characterization of a novel methanol dehydrogenase in representatives of Burkholderiales: implications for environmental detection of methylotrophy and evidence for convergent evolution. J Bacteriol. 2008;190(11):3817-23. https://doi.org/10.1128/JB.00180-08.

84. Reddy SY, Bruice TC. Mechanisms of ammonia activation and ammonium ion inhibition of quinoprotein methanol dehydrogenase: a computational approach. Proc Natl Acad Sci U S A. 2004;101(45):15887-92. https://doi.org/1 0.1073/pnas.0407209101

85. Culpepper MA, Rosenzweig AC. Structure and protein-protein interactions of methanol dehydrogenase from Methylococcus capsulatus (Bath). Biochemistry. 2014;53(39):6211-9. https://doi.org/10.1021/bi500850j.

86. Deng YW, Ro SY, Rosenzweig AC. Structure and function of the lanthanidedependent methanol dehydrogenase XoxF from the methanotroph Methylomicrobium buryatense 5GB1C. J Biol Inorg Chem. 2018;23(7):103747. https://doi.org/10.1007/s00775-018-1604-2.

87. Picone N. Op den Camp HJ: Role of rare earth elements in methanol oxidation. Curr Opin Chem Biol. 2019;49:39-44. https://doi.org/10.1016/j. cbpa.2018.09.019.

88. Huang J, Yu Z, Chistoserdova L. Lanthanide-dependent methanol dehydrogenases of XoxF4 and XoxF5 clades are differentially distributed among methylotrophic bacteria and they reveal different biochemical properties. Front Microbiol. 2018;9:1366. https://doi.org/10.3389/fmicb.2018.01366.

89. Bogart JA, Lewis AJ, Schelter EJ. DFT study of the active site of the XoxFtype natural, cerium-dependent methanol dehydrogenase enzyme. Chemistry. 2015;21(4):1743-8. https://doi.org/10.1002/chem.201405159.

90. Akberdin IR, Thompson M, Hamilton R, Desai N, Alexander D, Henard CA, et al. Methane utilization in Methylomicrobium alcaliphilum 20ZR: a systems approach. Sci Rep. 2018;8(1):2512. https://doi.org/10.1038/s41 598-018-20574-z

91. Keltjens JT, Pol A, Reimann J. Op den Camp HJ: PQQ-dependent methano dehydrogenases: rare-earth elements make a difference. Appl Microbiol Biotechnol. 2014;98(14):6163-83. https://doi.org/10.1007/s00253-014-5766-8.

92. Good NM, Moore RS, Suriano CJ, Martinez-Gomez NC. Contrasting in vitro and in vivo methanol oxidation activities of lanthanide-dependent alcohol dehydrogenases XoxF1 and ExaF from Methylobacterium extorquens AM1. Sci Rep. 2019;9(1):4248. https://doi.org/10.1038/s41598-019-41043-1.

93. Akberdin IR, Collins DA, Hamilton R, Oshchepkov DY, Shukla AK, Nicora CD, et al. Rare earth elements alter redox balance in Methylomicrobium alcaliphilum 20Z(R). Front Microbiol. 2018:9:2735. https://doi.org/10.3389/ fmicb.2018.02735.

94. Khmelenina W, Murrell JC, Smith TJ, Trotsenko YA, Rojo F. Physiology and biochemistry of the aerobic methanotrophs. In: Aerobic utilization of 
hydrocarbons oils and lipids handbook of hydrocarbon and lipid microbiology. Edited by Rojo F. Cham: Springer Nature; 2018. p. 1-25.

95. Chistoserdova L, Vorholt JA, Lidstrom ME. A genomic view of methane oxidation by aerobic bacteria and anaerobic archaea. Genome Biol. 2005; 6(2):208. https://doi.org/10.1186/gb-2005-6-2-208.

96. Matsen JB, Yang S, Stein LY, Beck D, Kalyuzhnaya MG. Global molecular analyses of methane metabolism in Methanotrophic Alphaproteobacterium, Methylosinus trichosporium OB3b. Part I: Transcriptomic Study. Front Microbiol. 2013;4:40

97. Stein $L Y$, Yoon S, Semrau JD, Dispirito AA, Crombie A, Murrell JC, et al. Op den Camp HJ, Bringel F et al: Genome sequence of the obligate methanotroph Methylosinus trichosporium strain OB3b. J Bacteriol. 2010; 192(24):6497-8. https://doi.org/10.1128/JB.01144-10.

98. Vorholt JA, Chistoserdova L, Stolyar SM, Thauer RK, Lidstrom ME. Distribution of tetrahydromethanopterin-dependent enzymes in methylotrophic bacteria and phylogeny of methenyl tetrahydromethanopterin cyclohydrolases. J Bacteriol. 1999;181(18):57507. https://doi.org/10.1128/JB.181.18.5750-5757.1999.

99. Zahn JA, Bergmann DJ, Boyd JM, Kunz RC, DiSpirito AA. Membraneassociated quinoprotein formaldehyde dehydrogenase from Methylococcus capsulatus Bath. J Bacteriol. 2001;183(23):6832-40. https://doi.org/10.1128/ JB.183.23.6832-6840.2001

100. Stirling DI, Dalton H. Purification and properties of an NAD(P)+-linked formaldehyde dehydrogenase from Methylococcus capsulatus (Bath). I Gen Microbiol. 1978;107(1):19-29. https://doi.org/10.1099/00221287-107-1-19.

101. Tate S, Dalton H. A low-molecular-mass protein from Methylococcus capsulatus (Bath) is responsible for the regulation of formaldehyde dehydrogenase activity in vitro. Microbiology (Reading). 1999;145(Pt 1):15967. https://doi.org/10.1099/13500872-145-1-159.

102. Adeosun EK, Smith TJ, Hoberg AM, Velarde G, Ford R, Dalton H. Formaldehyde dehydrogenase preparations from Methylococcus capsulatus (Bath) comprise methanol dehydrogenase and methylene tetrahydromethanopterin dehydrogenase. Microbiology (Reading). 2004; 150(Pt 3):707-13. https://doi.org/10.1099/mic.0.26707-0.

103. Jollie DR, Lipscomb JD. Formate dehydrogenase from Methylosinus trichosporium OB3b. Purification and spectroscopic characterization of the cofactors. J Biol Chem. 1991;266(32):21853-63. https://doi.org/10.1016/ S0021-9258(18)54716-5.

104. Waldron KJ, Robinson NJ. How do bacterial cells ensure that metalloproteins get the correct metal? Nat Rev Microbiol. 2009;7(1):25-35. https://doi.org/10.1038/nrmicro2057.

105. Koh E-I, Henderson JP. Microbial copper-binding siderophores at the hostpathogen interface. J Biol Chem. 2015;290(31):18967-74. https://doi.org/10.1 074/jbc.R115.644328.

106. Balasubramanian R, Kenney GE, Rosenzweig AC. Dual pathways for copper uptake by methanotrophic bacteria. J Biol Chem. 2011;286(43):37313-9. https://doi.org/10.1074/jbc.M111.284984.

107. Gu W, Farhan UI Haque M, Baral BS, Turpin EA, Bandow NL, Kremmer E, et al. A TonB-Dependent transporter is responsible for methanobactin uptake by Methylosinus trichosporium OB3b. Appl Environ Microbiol. 2016; 82(6):1917-23. https://doi.org/10.1128/AEM.03884-15.

108. Vollan HS, Tannæs T, Vriend G, Bukholm G. In silico structure and sequence analysis of bacterial porins and specific diffusion channels for hydrophilic molecules: conservation, multimericity and multifunctionality. Int J Mol Sci. 2016;17(4):599.

109. Kim HJ, Graham DW, DiSpirito AA, Alterman MA, Galeva N, Larive CK, et al. Methanobactin, a copper-acquisition compound from methane-oxidizing bacteria. Science. 2004;305(5690):1612-5. https://doi.org/10.1126/science.1 098322.

110. Helland R, Fjellbirkeland A, Karlsen OA, Ve T, Lillehaug JR, Jensen HB. An oxidized tryptophan facilitates copper binding in Methylococcus capsulatussecreted protein MopE. J Biol Chem. 2008;238:13897-904

111. Kenney GE, Dassama LMK, Pandelia M-E, Gizzi AS, Martinie RJ, Gao P, et al. The biosynthesis of methanobactin. Science. 2018;359(6382):1411-6. https:// doi.org/10.1126/science.aap9437.

112. Semrau JD, DiSpirito AA, Obulisamy PK, Kang-Yun CS. Methanobactin from methanotrophs: genetics, structure, function and potential applications. FEMS Microbiol Lett. 2020;367(5):fnaa045.

113. Dassama LMK, Kenney GE, Rosenzweig AC. Methanobactins: from genome to function. Metallomics. 2017:9(1):7-20. https://doi.org/10.103 9/C6MT00208K.
114. Choi DW, Bandow NL, McEllistrem MT, Semrau JD, Antholine WE, Hartsel SC, et al. Spectral and thermodynamic properties of methanobactin from $\gamma^{-}$ proteobacterial methane oxidizing bacteria: a case for copper competition on a molecular level. J Inorg Biochem. 2010;104(12):1240-7. https://doi.org/1 0.1016/j.jinorgbio.2010.08.002.

115. Choi DW, Zea CJ, Do YS, Semrau JD, Antholine WE, Hargrove MS, et al. Spectral, kinetic, and thermodynamic properties of $\mathrm{Cu}(\mathrm{l})$ and $\mathrm{Cu}(\mathrm{Il})$ binding by methanobactin from Methylosinus trichosporium OB3b. Biochemistry. 2006;45(5):1442-53. https://doi.org/10.1021/bi051815t.

116. Baslé A, El Ghazouani A, Lee J, Dennison C. Insight into metal removal from peptides that sequester copper for methane oxidation. Chemistry. 2018; 24(18):4515-8. https://doi.org/10.1002/chem.201706035.

117. Kang CS, Dunfield PF, Semrau JD. The origin of aerobic methanotrophy within the Proteobacteria. FEMS Microbiol Letts. 2019;366(9):fnz096.

118. McCabe JW, Vangala R, Angel LA. Binding selectivity of methanobactin from Methylosinus trichosporium OB3b for copper(I), silver(I), zinc(II), nickel(II), cobalt(II), manganese(II), lead(II), and iron(II). J Am Soc Mass Spectr. 2017; 28(12):2588-601. https://doi.org/10.1007/s13361-017-1778-9.

119. Baral BS, Bandow NL, Vorobev A, Freemeier BC, Bergman BH, Herdendorf TJ, et al. Mercury binding by methanobactin from Methylocystis strain SB2. J Inorg Biochem. 2014;141:161-9. https://doi.org/10.1016/j.jinorgbio.2014.09.004.

120. Yin X, Wang L, Zhang L, Chen H, Liang X, Lu X, et al. Synergistic effects of a chalkophore, methanobactin, on microbial methylation of mercury. Appl Environ Microbiol. 2020;86(11):e00122-20.

121. Choi DW, Do YS, Zea CJ, McEllistrem MT, Lee S-W, Semrau JD, et al. Spectral and thermodynamic properties of $\mathrm{Ag}(\mathrm{I}), \mathrm{Au}(\mathrm{III)}, \mathrm{Cd}(\mathrm{II}), \mathrm{Co}(\mathrm{II}), \mathrm{Fe}(\mathrm{III}), \mathrm{Hg}(\mathrm{II})$, $\mathrm{Mn}(\mathrm{II}), \mathrm{Ni}(\mathrm{II}), \mathrm{Pb}(\mathrm{II}), \mathrm{U}(\mathrm{I})$, and $\mathrm{Zn}(\mathrm{II})$ binding by methanobactin from Methylosinus trichosporium OB3b. J Inorg Biochem. 2006;100(12):2150-61. https://doi.org/10.1016/j.jinorgbio.2006.08.017.

122. Dennison C, David S, Lee J. Bacterial copper storage proteins. J Biol Chem. 2018;293(13):4616-27. https://doi.org/10.1074/jbc.TM117.000180.

123. Fjellbirkeland A, Kruger PG, Bemanian V, Høgh BT, Murrell JC, Jensen HB. The C-terminal part of the surface-associated protein MopE of the methanotroph Methylococcus capsulatus (Bath) is secreted into the growth medium. Arch Microbiol. 2001;176(3):197-203. https://doi.org/10.1007/s002 030100307.

124. Martinho M, Choi DW, Dispirito AA, Antholine WE, Semrau JD, Münck E. Mössbauer studies of the membrane-associated methane monooxygenase from Methylococcus capsulatus bath: evidence for a Diiron center. J Am Chem Soc. 2007;129(51):15783-5. https://doi.org/10.1021/ja077682b.

125. Semrau JD, Jagadevan S, DiSpirito AA, Khalifa A, Scanlan J, Bergman BH, et al. Methanobactin and MmoD work in concert to act as the 'copperswitch' in methanotrophs. Environ Microbiol. 2013;15(11):3077-86. https:// doi.org/10.1111/1462-2920.12150.

126. El Ghazouani A, Baslé A, Gray J, Graham DW, Firbank SJ, Dennison C. Variations in methanobactin structure influences copper utilization by methane-oxidizing bacteria. P Natl Acad Sci USA. 2012;109(22):8400-4 https://doi.org/10.1073/pnas.1112921109.

127. Jahng D, Wood T. Metal ions and chloramphenicol inhibition of soluble methane monooxygenase from Methylosinus trichosporium OB3b. Appl Microbiol Biotechnol. 1996:45(6):744-9. https://doi.org/10.1007/s00253 0050757.

128. Pesch M-L, Christl I, Hoffmann M, Kraemer SM, Kretzschmar R. Copper complexation of methanobactin isolated from Methylosinus trichosporium OB3b: pH-dependent speciation and modeling. J Inorg Biochem. 2012;116: 55-62. https://doi.org/10.1016/j.jinorgbio.2012.07.008.

129. Vita N, Platsaki S, Baslé A, Allen SJ, Paterson NG, Crombie AT, et al. A fourhelix bundle stores copper for methane oxidation. Nature. 2015;525(7567): 140-3. https://doi.org/10.1038/nature14854.

130. Vita N, Landolfi G, Baslé A, Platsaki S, Lee J, Waldron KJ, et al. Bacterial cytosolic proteins with a high capacity for $\mathrm{Cu}(\mathrm{I})$ that protect against copper toxicity. Sci Rep. 2016;6(1):39065. https://doi.org/10.1038/srep39065.

131. Cornu JY, Huguenot D, Jezequel K, Lollier M, Lebeau T. Bioremediation of copper-contaminated soils by bacteria. World J Microbiol Biotechnol. 2017; 33(2):26. https://doi.org/10.1007/s11274-016-2191-4.

132. Cervantes C, Campos-García J, Devars S, Gutiérrez-Corona F, Loza-Tavera H, Torres-Guzmán JC, et al. Interactions of chromium with microorganisms and plants. FEMS Microbiol Rev. 2001;25(3):335-47. https://doi.org/10.1111/j.1 574-6976.2001.tb00581.x.

133. Beukes JP, du Preez SP, van Zyl PG, Paktunc D, Fabritius T, Paatalo M, et al. Review of $\mathrm{Cr}(\mathrm{Vl})$ environmental practices in the chromite mining and 
smelting industry - relevance to development of the Ring of Fire, Canada. J Clean Prod. 2017;165:874-89. https://doi.org/10.1016/j.jclepro.2017.07.176.

134. Coetzee JJ, Bansal N, Chirwa EMN. Chromium in environment, its toxic effect from chromite-mining and ferrochrome industries, and its possible bioremediation. Expo Health. 2020;12:51-62. https://doi.org/10.1007/s12403018-0284-z.

135. Krober E, Cunningham MR, Peixoto J, Spurgin L, Wischer D, Kruger R, et al. Comparative genomics analyses indicate differential methylated amine utilization trait within members of the genus Gemmobacter. Environ Microbiol Rep. 2021;13(2):195-208. https://doi.org/10.1111/1758-2229.12927.

136. Enbaia S, Eswayah A, Hondow N, Gardiner PHE, Smith TJ. Detoxification, active uptake, and intracellular accumulation of chromium species by a methane-oxidizing bacterium. Appl Environ Microbiol. 2021;87(2):e00947-20.

137. Challa S, Smith TJ. Isolation of a methane-oxidizing bacterium that bioremediates hexavalent chromium from a formerly industrialized Suburban River. Lett Appl Microbiol. 2020;71(3):287-93. https://doi.org/1 0.1111/lam.13330.

138. Qin H, Zhu J, Liang L, Wang M, Su H. The bioavailability of selenium and risk assessment for human selenium poisoning in high-Se areas, China. Environ Int. 2013;52:66-74. https://doi.org/10.1016/j.envint.2012.12.003.

139. Dungan RS, Frankenberger WT. Microbial transformations of selenium and the bioremediation of seleniferous environments. Bioremediat J. 1999;3(3): 171-88. https://doi.org/10.1080/10889869991219299.

140. Zhang JS, Gao XY, Zhang LD, Bao YP. Biological effects of a nano red elemental selenium. Biofactors. 2001;15(1):27-38. https://doi.org/10.1002/ biof.5520150103.

141. Schlekat CE, Dowdle PR, Lee BG, Luoma SN, Oremland RS. Bioavailability of particle-associated se to the bivalve Potamocorbula amurensis. Environ Sci Technol. 2000;34(21):4504-10. https://doi.org/10.1021/es001013f.

142. Lai CY, Wen LL, Shi LD, Zhao KK, Wang YQ, Yang $X$, et al. Selenate and nitrate bioreductions using methane as the electron donor in a membrane biofilm reactor. Environ Sci Technol. 2016;50(18):10179-86. https://doi.org/1 0.1021 /acs.est.6b02807

143. Nancharaiah YV, Lens PNL. Selenium biomineralization for biotechnological applications. Trends Biotechnol. 2015;33(6):323-30. https://doi.org/10.1016/j. tibtech.2015.03.004.

144. Oremland RS, Herbel MJ, Blum JS, Langley S, Beveridge TJ, Ajayan PM, et al. Structural and spectral features of selenium nanospheres produced by Serespiring bacteria. Appl Environ Microbiol. 1994;70:52-60.

145. Wang Y, Lai CY, Wu M, Song Y, Hu S, Yuan Z, et al. Roles of oxygen in methane-dependent selenate reduction in a membrane biofilm reactor: stimulation or suppression. Water Res. 2021;198:117150. https://doi.org/10.1 016/j.watres.2021.117150

146. Eswayah AS, Hondow N, Scheinost AC, Merroun M, Romero-Gonzalez M, Smith TJ, et al. Methyl selenol as a precursor in selenite reduction to $\mathrm{Se} / \mathrm{S}$ species by methane-oxidizing bacteria. Appl Environ Microbiol. 2019:85(22):e01379-19.

147. Wang D, Xia X, Wu S, Zheng S, Wang G. The essentialness of glutathione reductase GorA for biosynthesis of Se(0)-nanoparticles and GSH for CdSe quantum dot formation in Pseudomonas stutzeri TS44. J Hazard Mater. 2019;366:301-10. https://doi.org/10.1016/j.jhazmat.2018.11.092.

148. Kim M, Zoh K. Fate and transport of mercury in environmental media and human exposure. J Prev Med Public Health. 2012;45(6):335-43. https://doi. org/10.3961/jpmph.2012.45.6.335

149. Boden R, Murrell JC. Response to mercury (II) ions in Methylococcus capsulatus (Bath). FEMS Microbiol Letts. 2011;324(2):106-10. https://doi.org/1 0.1111/j.1574-6968.2011.02395.x.

150. Shi LD, Chen YS, Du JJ, Hu YQ, Shapleigh JP, Zhao HP. Metagenomic evidence for a methylocystis species capable of bioremediation of diverse heavy metals. Front Microbiol. 2018;9:3297.

151. Buey RM, Arellano JB, Lopez-Maury L, Galindo-Trigo S, Velazquez-Campoy A, Revuelta $J$, et al. Unprecedented pathway of reducing equivalents in a diflavin-linked disulfide oxidoreductase. Proc Natl Acad Sci U S A. 2017; 114(48):12725-30. https://doi.org/10.1073/pnas.1713698114.

152. Ajsuvakova OP, Tinkov AA, Aschner M, Rocha JBT, Michalke B, Skalnaya MG, et al. Sulfhydryl groups as targets of mercury toxicity. Coord Chem Rev. 2020;417:213343. https://doi.org/10.1016/j.ccr.2020.213343.

153. Ji M, Barnwell CV, Grunden AM. Characterization of recombinant glutathione reductase from the psychrophilic Antarctic bacterium Colwellia psychrerythraea. Extremophiles. 2015;19(4):863-74. https://doi.org/10.1007/ s00792-015-0762-1.
154. Nell RM, Fein JB. Influence of sulfhydryl sites on metal binding by bacteria. Geochim Cosmochim Acta. 2017;199:210-77. https://doi.org/10.1016/j.gca.2 016.11.039.

155. Mishra B, Shoenfelt E, Yu Q, Yee N, Fein JB, Myneni SCB. Stoichiometry of mercury-thiol complexes on bacterial cell envelopes. Chem Geol. 2017;464: 137-46. https://doi.org/10.1016/j.chemgeo.2017.02.015.

156. Moore MJ, Distefano MD, Zydowsky LD, Cummings RT, Walsh CT. Organomercurial lyase and mercuric ion reductase: nature's mercury detoxification catalysts. Acc Chem Res. 1990;23(9):301-8. https://doi.org/10.1 021/ar00177a006.

157. Rennex D, Cummings RT, Pickett M, Walsh $C T$, Bradley M. Role of tyrosine residues in mercury(II) detoxification by mercuric reductase from Bacillus $\mathrm{sp}$. strain RC607. Biochemistry. 1993;32(29):7475-8. https://doi.org/10.1021/ bi00080a019.

158. Stratton A, Ericksen M, Harris TV, Symmonds N, Silverstein TP. Mercury(II) binds to both of chymotrypsin's histidines, causing inhibition followed by irreversible denaturation/aggregation. Protein Sci. 2017;26(2):292-305. https://doi.org/10.1002/pro.3082.

159. Ngu-Schwemlein M, Merle JK, Healy P, Schwemlein S, Rhodes S. Thermodynamics of the complexation of $\mathrm{Hg}(\mathrm{II})$ by cysteinyl peptide ligands using isothermal titration calorimetry. Thermochim Acta. 2009;496(1):129-35. https://doi.org/10.1016/j.tca.2009.07.010.

160. Begley TP, Walts AE, Walsh CT. Bacterial organomercurial lyase: overproduction, isolation and characterization. Biochemistry. 1986;25(22): 7192-200. https://doi.org/10.1021/bi00370a064.

161. Lai CY, LV PL, Dong QY, Yeo SL, Rittmann BE, Zhao HP. Bromate and nitrate bioreduction coupled with poly-beta-hydroxybutyrate production in a methane-based membrane biofilm reactor. Environ Sci Technol. 2018;52(12): 7024-31. https://doi.org/10.1021/acs.est.8b00152.

162. Ho A, Angel R, Veraart AJ, Daebeler A, Jia Z, Kim SY, et al. Biotic interactions in microbial communities as modulators of biogeochemical processes: methanotrophy as a model system. Front Microbiol. 2016;7:1285.

163. Ho A, de Roy K, Thas O, De Neve J, Hoefman S, Vandamme P, et al. The more, the merrier: heterotroph richness stimulates methanotrophic activity. ISME J. 2014;8(9):1945-8. https://doi.org/10.1038/ismej.2014.74.

164. Stock M, Hoefman S, Kerckhof FM, Boon N, De Vos P, De Baets B, et al. Exploration and prediction of interactions between methanotrophs and heterotrophs. Res Microbiol. 2013;164(10):1045-54. https://doi.org/10.1016/j. resmic.2013.08.006.

165. Karthikeyan OP, Chidambarampadmavathy K, Nadarajan S, Lee PK, Heimann K. Effect of $\mathrm{CH} 4 / \mathrm{O} 2$ ratio on fatty acid profile and polyhydroxybutyrate content in a heterotrophic-methanotrophic consortium. Chemosphere. 2015;141:235-42. https://doi.org/10.1016/j.chemosphere.2015.07.054.

166. Zhu J, Xu X, Yuan M, Wu H, Ma Z, Wu W. Optimum O2:CH4 ratio promotes the synergy between aerobic methanotrophs and denitrifiers to enhance nitrogen removal. Front Microbiol. 2017:8:1112. https://doi.org/10.3389/ fmicb.2017.01112.

167. Chidambarampadmavathy K, Karthikeyan OP, Huerlimann R, Maes GE, Heimann K. Responses of mixed methanotrophic consortia to variable $\mathrm{Cu}(2+) / \mathrm{Fe}(2+)$ ratios. J Environ Manag. 2017;197:159-66. https://doi.org/10.1 016/j.jenvman.2017.03.063.

\section{Publisher's Note}

Springer Nature remains neutral with regard to jurisdictional claims in published maps and institutional affiliations.

Ready to submit your research? Choose BMC and benefit from:

- fast, convenient online submission

- thorough peer review by experienced researchers in your field

- rapid publication on acceptance

- support for research data, including large and complex data types

- gold Open Access which fosters wider collaboration and increased citations

- maximum visibility for your research: over $100 \mathrm{M}$ website views per year

At $\mathrm{BMC}$, research is always in progress.

Learn more biomedcentral.com/submissions 